\title{
Housing Buildings' Characterization at Corvo Village (Azores) Historical Center: Towards a Sustainable Rehabilitation Process
}

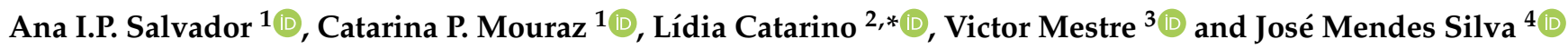 \\ 1 Department of Civil Engineering, University of Coimbra, 3030-788 Coimbra, Portugal; \\ ana.ip.salvador@azores.gov.pt (A.I.P.S.); catarinamouraz@hotmail.com (C.P.M.) \\ 2 Geosciences Center, Earth Sciences Department, University of Coimbra, 3030-790 Coimbra, Portugal \\ 3 Department of Architecture, University of Coimbra, 3000-143 Coimbra, Portugal; vm@mestrealeixo.pt \\ 4 ADAI, Department of Civil Engineering, University of Coimbra, 3030-788 Coimbra, Portugal; \\ raimundo@dec.uc.pt \\ * Correspondence: lidiagil@dct.uc.pt
}

Citation: Salvador, A.I.P.;

Mouraz, C.P.; Catarino, L.; Mestre, V.; Silva, J.M. Housing Buildings'

Characterization at Corvo Village (Azores) Historical Center: Towards a Sustainable Rehabilitation Process. Sustainability 2021, 13, 2352.

https://doi.org/10.3390/su13042352

Academic Editor: Asterios Bakolas

Received: 20 January 2021

Accepted: 17 February 2021

Published: 22 February 2021

Publisher's Note: MDPI stays neutral with regard to jurisdictional claims in published maps and institutional affiliations.

Copyright: (c) 2021 by the authors. Licensee MDPI, Basel, Switzerland. This article is an open access article distributed under the terms and conditions of the Creative Commons Attribution (CC BY) license (https:// creativecommons.org/licenses/by/ $4.0 /)$.

\begin{abstract}
Corvo is the smallest island of the Portuguese archipelago of the Azores and an unexplored territory, with one single village. Scarce studies have been conducted regarding its built heritage, and deep knowledge of the constructions is necessary for conservation actions to be carried out. This article presents the architectonic and constructive characterization of housing building features that compose Corvo village's historical center, focusing on its characteristics, dissonances, and conservation state. A case study regarding one housing building is presented. This research intends to contribute to a deeper knowledge of these buildings' identity, constituting the first step towards future rehabilitation processes that can improve the inhabitants' quality of life and simultaneously value the territory's singularity.
\end{abstract}

Keywords: architectonic characterization; constructive characterization; heritage; rehabilitation processes; sustainable construction; resilient communities; architectonic identity

\section{Introduction}

Corvo Island is the smallest island in the Autonomous Region of the Azores, Portugal (Figure 1). Formed by volcanic activity, it presents an area of $17.12 \mathrm{~km}^{2}$ and has been listed as a Biosphere Reserve by UNESCO since 2007. The only village on the island, with 440 inhabitants, is located on its south side, in a lava delta (a small area of flat fertile land at the bottom of a seaside cliff composed of volcanic and geomorphological debris, Figure 2). The village's historical center (Núcleo Antigo da Vila do Corvo-NAVC) has its origin in the 16th century and has been classified as a protected urban site of public interest by the Azores Regional Government since 1997 [1]. This classification is applied when the site's protection and enhancement represent a cultural value of national importance, but for which the regime formally classified as "national interest" is disproportionate [2].

Unlike other Azorean islands, Corvo remains an unexplored territory in many ways, usually described by the small number of inhabitants rather than the singularities of its identity. Several works have been developed regarding the characterization of the built heritage in other Azorean islands [3,4]. However, due to the Azorean archipelago location within the boundary between the Eurasian, African, and American plates [5], which has led to severe seismic activity and even catastrophic events, research is mainly conducted towards the assessment of buildings' seismic vulnerability, both in the Azores in general [6] and on specific islands [7-9]. Despite the importance of this topic, studies in several Azorean territories such as Corvo Island are still scarce [10,11], especially regarding its built heritage. 


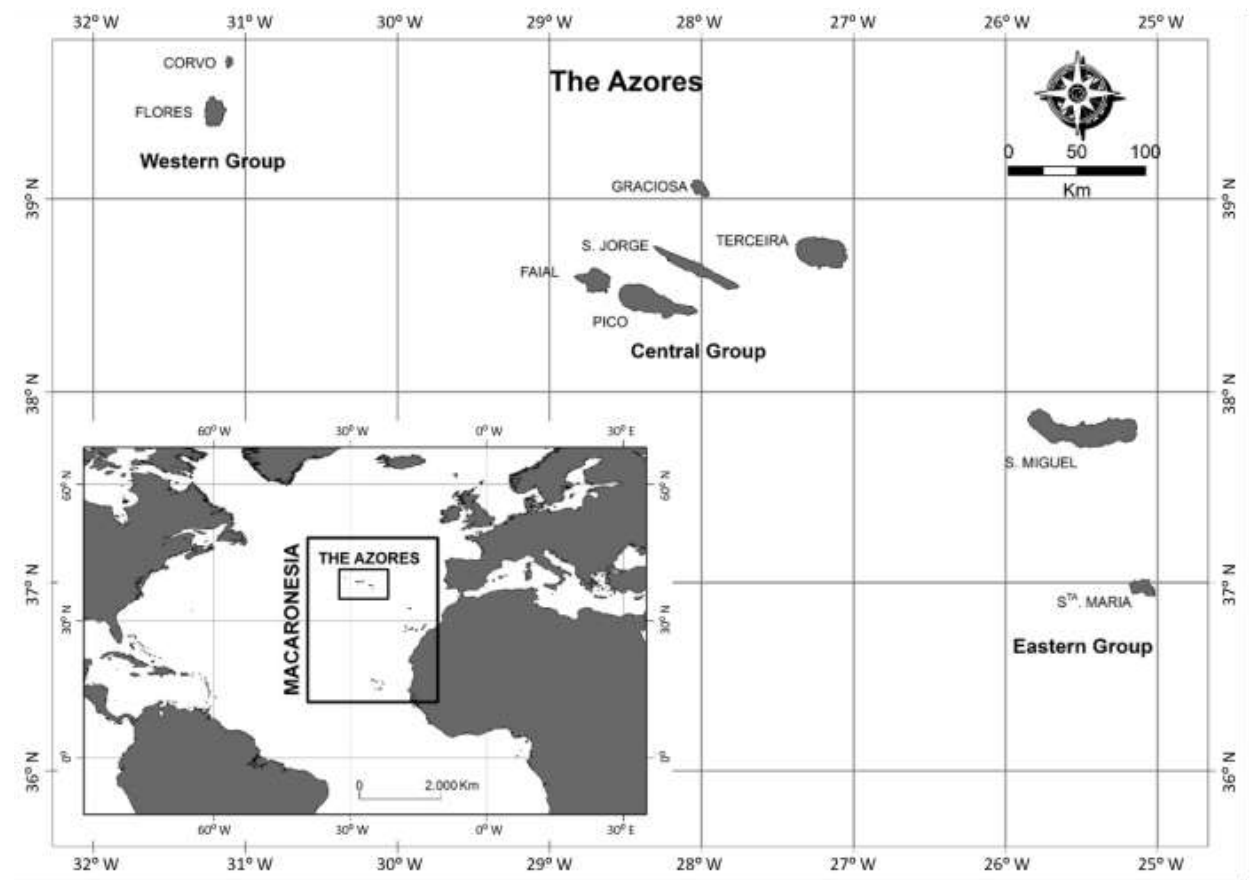

Figure 1. Location of the Azores archipelago (Portugal) and Corvo Island [12].

Since 2014 there has been extensive work developed by the Regional Directorate for the Culture of the Azores (Direção Regional de Cultura dos Açores) to promote and develop Corvo Island's Ecomuseum project, with the main goal of recognizing and identifying the island's identity, taking into account the participation of its community and perceiving this territory as a catalyst for local socioeconomic development capable of generating wealth and serving community interests [13]. This project includes the conservation of NAVC's built heritage, which began with extensive work of in loco characterization and an analysis of NAVC buildings' identity, which was developed by the Local Technical Office created for that purpose, composed of a team of architects and engineers since 2018. This process is particularly meaningful due to the importance of deep technical knowledge of the buildings' architectural and constructive features, contributing to sustained choices of conservation and rehabilitation solutions.
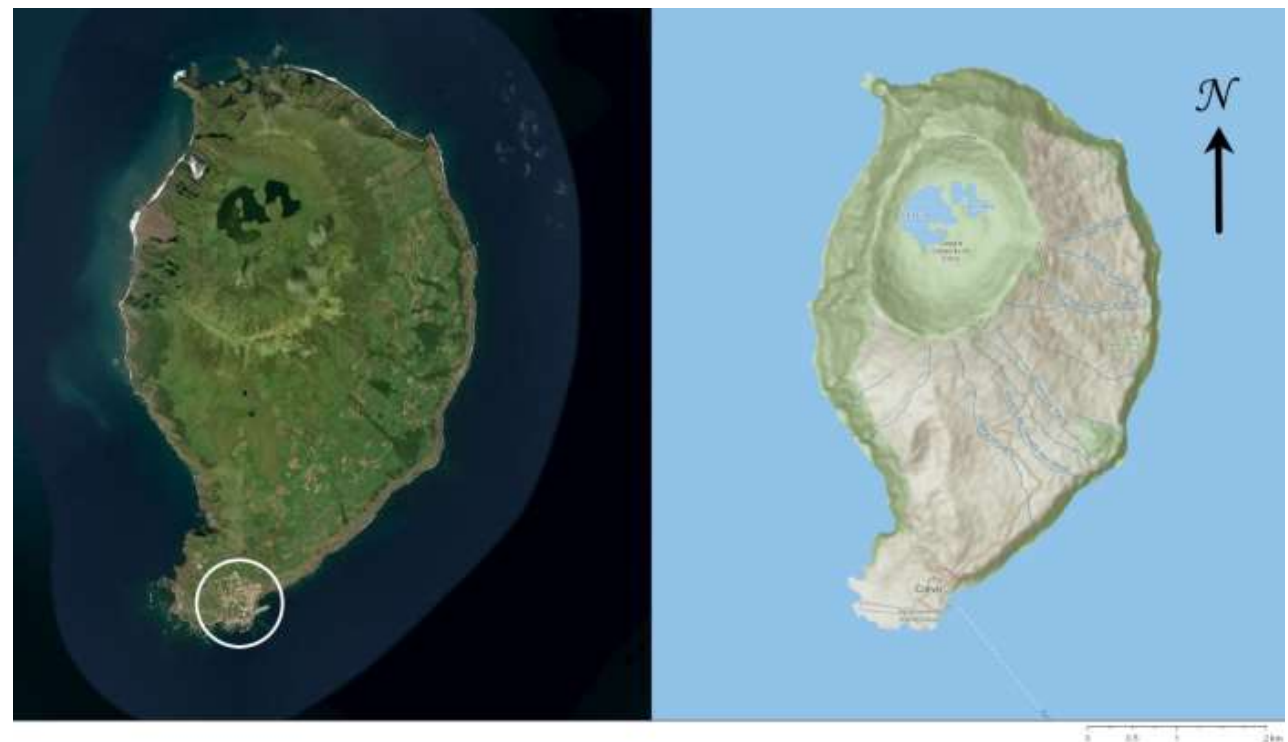

Figure 2. General aerial and topographic view of Corvo Island and the location of Corvo village [14]. 
Due to the fact that studies regarding Corvo Island are scarce and outdated, it is important to identify the architectonical and constructive characteristics of the village's constructions, contributing to a progressive knowledge of this territory's identity and laying the foundations for future rehabilitation processes. In order to support actions aiming to preserve and enhance the quality of the human environment [15], it is necessary to better integrate urban heritage conservation strategies within the larger goals of overall sustainable development.

Strategies such as the Ecomuseum project are important approaches that value the territory's identity through its conservation, with the main goal of improving the inhabitants' quality of life. However, different contexts require different approaches, which can be clearly identified in other Azorean islands and in other European contexts.

Considering international contexts, there is a wide range of examples of research studies dedicated to the characterization of building types in historic centers, which are fundamental to these territories' conservation. Regarding Mediterranean countries, the Italian studies conducted on Sardinia island and the technical manuals developed are important references [16]. In other territories, such as the Abruzzo region, there are also examples of detailed documents published [17]. In Spain, significant technical advances have also been made considering different historical territories [18,19].

Regarding the Azorean context, and taking Santa Maria Island as an example, studies are being conducted considering the housing dwellings that compose "Bairro do Aeroporto," a residential neighborhood of significant dimensions near the airport of Vila do Porto, built in the middle of the 20th century [20]. A strategy towards the conservation of the place and its revitalization is being carried out, considering the rehabilitation of housing dwellings as well as the implementation of economic, tourist, and cultural activities. A different approach was followed in Angra do Heroísmo, Terceira Island. The main process that took place towards the town's conservation was in 1980, after a major earthquake that destroyed a significant part of its buildings. In addition, the objective of attaining the classification of UNESCO World Heritage site contributed to a strict process of conservation actions, which led to the classification in 1983 [21]. These cases represent examples of how different territories involved different approaches regarding large-scale rehabilitation actions, underlining the existence of diverse contexts that are important to consider individually in order to coherently achieve specific goals.

Considering the Ecomuseum project contributions so far, the results of an MSc thesis on building rehabilitation [22], and previous technical and scientific contributions made towards the characterization of NAVC [23], the aim of this article is to summarize and present the architectonic and constructive characterization of the housing buildings in NAVC, laying the foundations for future conservation and rehabilitation processes within the scope of the Ecomuseum project. Information regarding the materials and local resources of Corvo Island and NAVC is presented, as well as a state of conservation synthesis and the buildings' most relevant dissonances. Additionally, a case study regarding a NAVC building rehabilitation intervention is presented.

\section{Historical Context and Community Description}

The discovery of the Azores and the settlement of its population are themes shrouded in uncertainty. However, it is commonly accepted that the Azores archipelago was first discovered, depopulated, in 1427 by Diogo de Silves, Santa Maria Island being the first to be discovered. In 1439, the introduction of sheep on seven islands of the Azores was ordered by Afonso V (all islands except Flores and Corvo) [11]. However, other sources document the arrival of Gonçalo Zarco to Santa Maria Island in 1431 followed by the (re)discovery-or recognition-of six other islands from east to west in the subsequent years [24].

Nonetheless, the remaining islands, Flores and Corvo, were identified in 1452 by Diogo de Teive, while returning from an exploratory trip to the northeast Atlantic [25]. Information related to the population settlement in the Azores refers to it as slow and arduous, occurring in phases from east to west, starting in Santa Maria and taking almost 
a century to be extended to the other islands [25]. With the discovery of America and of the sea route around Africa on the way to India in 1498, the Azores became an invaluable territory in the middle of the north Atlantic.

Until 1853 the island of Corvo was ruled by an owner to whom the inhabitants (corvinos) had to pay taxes (Figure 3). The first settlement phase was implemented in 1503-1508 with low success. After that initial phase, only the cattle remained. Two other settlement phases were carried out in 1548 and 1593.

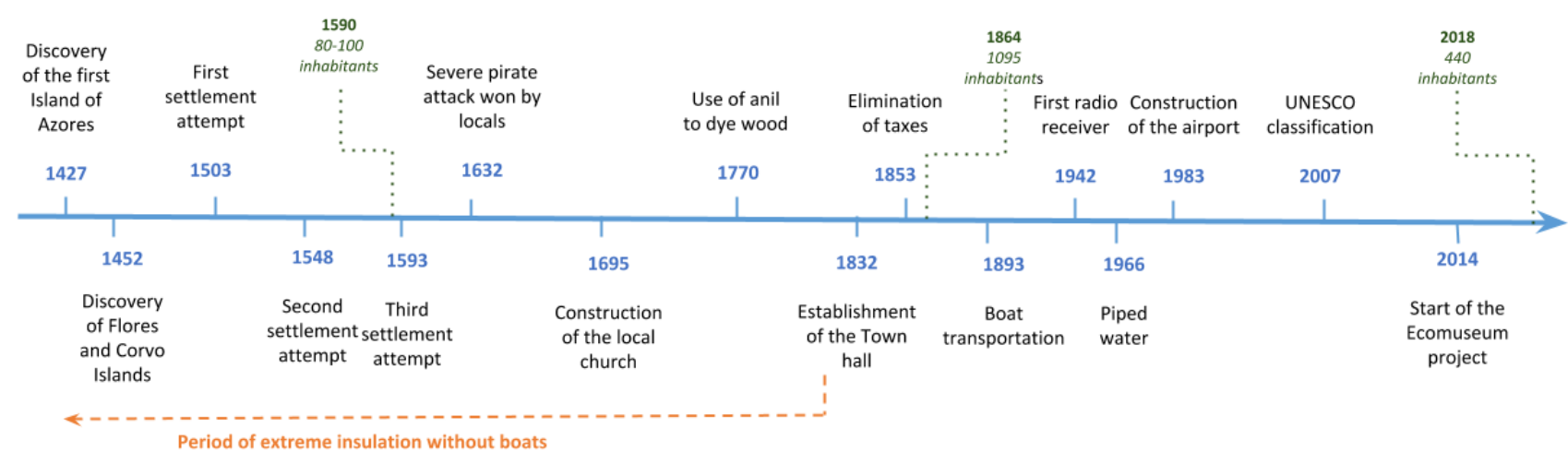

Figure 3. Corvo Island's timeline of the main events.

During the 16th and 17th centuries, attacks by pirates were frequent and the island had no communications with the outside.

In 1853, after several complaints, the tax system was removed, and farmers were able to buy their own land to raise cattle. The municipality became official and the selling of groceries to the ships' crews was a new way of achieving some profit.

Until the 19th century, the communication with the exterior, including others island of the archipelago, remained minimal. Emergency communications were carried out by smoke signals to the nearest island (Flores). Boats, even for fishing, were nonexistent. It is likely that this situation helped prevent workers from escaping. In 1893 the first ferry started a regular route to other islands of the archipelago every three months.

The 20th century brought some improvements to the lifestyle of the corvinos with a radio receiver and piped water supply. After Portugal's Carnation Revolution in 1974, the improvement in living conditions and habitability was a priority, and the construction of the airport and other infrastructure was carried out.

The implementation of sustainable practices to reduce dependence on imported goods is currently being developed. In 2011-2012, regarding liquefied petroleum gas usage, solar thermal systems and heat pumps were installed in each home to provide domestic hot water [26].

Regarding Corvo's population, the inhabitants always had a self-sufficient life and a strong sense of community, yet with limited resources.

The way of life and social dynamics were based on communitarianism, where residents had their private properties and access to a collective set of rights to be enjoyed by all families, based on a reciprocity of duties and rights known as community solidarity [10]. A large part of the island's area owned by the community was occupied by common land where animals were raised, wood was collected, and birds were hunted.

Corvo's population composed an agro-pastoral community where everyone collaborated and family work corresponded to both domestic and agricultural tasks. The island's economy was based on agriculture and grazing [27] and several reports indicate the extreme poverty of the people [22], which prevailed until the 20th century.

In addition to the exchange of several agricultural and cattle products, free or reciprocal work was also done for specific needs, such as the construction of houses. Corvinos also 
collaborated on the conservation work of the common land, or on the conservation and improvement works of the village [10].

In terms of human relationships, they were conditioned by age and sex. The elders had full authority over the youngest, and the men over the women. The domestic group usually constituted three generations. At the community level, the relations were egalitarian, with no hierarchy between domestic groups. Decisions that had to be made and implemented for the benefit of the community were solved together by all families, through their spokespersons and representatives, such as the elders and the priests.

Currently, most of the active population works in the secondary and tertiary sectors, such as the city hall, municipal library, schools, public delegations, private services, or the airport, among others. Agriculture and fishing practices still exist, although there are only four full-time farmers and five professional fishing vessels. The services that require more training or higher education are, as a rule, occupied by foreign people. There are no unemployed inhabitants.

In addition, in the last years the number of inhabitants has increased, and the living conditions have also significantly improved due to significant developments in terms of communications, accessibility, and access to health.

Usually visitors have a predetermined idea that Corvo is an isolated, inhospitable, and gloomy place, as well as mysterious, curious, and even magical. After visiting, some are delighted and recognize the unusual characteristics of the island and the community, valuing its resilience. There are also others who feel surprised about how people can live with so many difficulties.

There is still a strong sense of community among the inhabitants, who highly value safety and quality of life. This aspect is also mentioned by tourists, especially the ones who stay on Corvo for more than one day and choose to stay longer on the island.

\section{Materials and Local Resources}

The geological formation of Corvo Island is reported as the most recent from the Azores archipelago, with $0.71 \mathrm{Ma}$ [28]. The two main geomorphologic entities correspond to the larger central volcano with a summit caldera, and a younger crater row on the southern flank of the central volcano, from which lava flowed down the slope, which eventually created a coastal lava delta at the southern part of the island [29].

In this delta, the platform where the village is located has a slope between 5-15\% (the small area where the airport was built has a slope under 5\%). Only $16.9 \%$ of the island has an altitude lower than $150 \mathrm{~m}$, and most buildings face south and east [28], being protected from the excessive wind.

The island's climate presents characteristics of being maritime temperate with low thermal amplitude, high precipitation, high air humidity, and persistent wind [30]. The mean annual rainfall corresponds to $1145 \mathrm{~mm}$ and the distribution of precipitation throughout the year is uneven, with higher precipitation values recorded during the season between September and March [29]. Climate conditions played an important role in the dwellings' evolution, especially the wind, which is a factor of primordial importance for the orientation and location of the chimneys and threshing floors.

Located to the west of the Middle Atlantic Ridge and integrated into the North American Plate, the island does not reveal significant effects of seismic action, as other Azores islands do [6]. From the geological point of view, the existing rocks are mainly basalts, trachyte and trachybasalt, tuff (sometimes with palagonite), and volcanic breach [28,31]. Vacuole basalts have sometimes interspersed levels of pyroclastic material composed of cinder, ash, and lapilli in levels [28], as can be observed in the ancient quarry. Different stones can be found in the buildings' masonry walls without a selective category, but commonly mixed in the same wall.

The small area used for the implantation of the villa on the southeast side of the lava delta is formed by pyroclastic friable material with cinder, ash, and pumices tuff $[28,32]$. The chemical degradation and weathering of these pyroclastic materials facilitate the formation 
of clay, which is useful as raw material in construction and roof tiles. The material was collected in the proximity of the places where homes were to be built.

For the roofs and several other uses in construction, the wood originated from two different sources: the forest of Azorean laurisilva, and shipwrecks. Generally, acacia, oak, chestnut, and cedar were the ones composing the native forest. In 1850 only $5.44 \mathrm{~km}^{2}$ of the island was native forest [33], and it was extinguished during the mid-20th century [34]. Pine tree wood was not present in the original forest, and its current presence in construction materials and elements indicates that this material came from shipwrecks that occurred near the island.

The proximity to the sea frequently damages metallic elements used in construction. Due to this fact, one of the buildings' singularities can be found in the traditional door locks, which are exclusively made of wood, and still function after decades of usage.

\section{Characterization of the Case Study}

\subsection{Architectonic Characterization}

\subsubsection{Overview and Urban Context}

This section presents the architectonic characterization of NAVC buildings and brief considerations regarding the village's urban context. Then, a detailed volumetric and functional characterization of the case study is presented. This information is particularly important not only to comprehend the buildings' organization, but also to support the definition of future intervention strategies in which the preservation of identity values should be compatible with a sustainable approach and the improvement of the quality of life.

Regarding its urban context, NAVC's core has a consolidated structure that is organized around a dozen small streets that lead to the port area and are drawn parallel to the sea, with a sinuous and irregular matrix. Small public squares and threshing floors, once shared by the community, are prominent in this structure.

Although this work is centered on the common built heritage, it is important to note that NAVC's urban organization and the history of its evolution was limited by the need to adapt to the place and its climate, establishing housing dwellings in a lower area, closer to the port, providing the most fertile land for agriculture and preparing the grouping of buildings for mutual help and protection.

\subsubsection{Volumetric and Functional Characterization of NAVC's Typical Housing Dwelling} Analysis Parameters

The identification and registration of the buildings' most common volumetric and functional characteristics in an urban complex, as well as their variants, is essential for understanding. The most relevant variables in this context are (i) floor plans and elevation dimensions, (ii) the geometry of implantation, (iii) the number of floors, and (iv) the relationship with the surrounding topography.

The exterior shape of the buildings, characterized by these indicators, is directly related to the urban, social, and economic organization of the place, reflecting its history and the evolution of the communities' way of life and also the construction materials and techniques. The exterior shape limits the functional organization of the home and is also influenced by it, being relevant in the context of (i) the shape of the compartments, (ii) their relative location, and (iii) the way they interconnect, either through (iiia) horizontal or (iiib) vertical circulations. Considering NAVC buildings' functional organization, elements such as the kitchen and the stairs, whether outside or inside, are particularly important.

In previous studies $[10,11]$ several types of relationships between the shape and the functional organization of these buildings were identified:

1. Rectangular-shaped floor plan, divided into a lower floor (kitchen and "cellar") and upper floor ("dining room" and bedrooms, which can be organized in a single row in smaller buildings, or, in larger buildings, in other spatial organizations); 
2. Rectangular-shaped floor plan, divided into a lower floor (kitchen and "cellar") and upper floor ("dining room" and bedrooms, spatially organized in a single row, but in which the access is granted through an entering space);

3. Rectangular-shaped floor plan, divided into a lower floor ("cellar") and upper floor (central "dining room" with two accesses, one to the bedroom and the other to the kitchen); and

4. L-shaped floor plan divided into a lower floor (kitchen and "cellar") and upper floor (central "dining room" that grants access to the bedrooms, which can be connected).

To clarify the terminology used in this text, it should be noted that "cellar" refers to a compartment on the ground floor not intended for living, which can have different functions: cellar, in the common sense, storage of food and agricultural tools, as well as, although more rarely, shelter for small animals. In addition, regarding housing itself, the designation "dining room" corresponds to a multipurpose space for common use in which the predominant piece of furniture is a table. Given the dwellings' small dimensions, this space can be used as a dining room, living room, or even to accommodate other common uses.

In the study area, there are currently 185 buildings with a predominant residential function: $140(75.68 \%)$ have a rectangular-shaped floor plan, $29(15.68 \%)$ have an L-shaped floor plan, $9(4.86 \%)$ present other shapes, usually composed of different volumes, and the remaining $7(3.78 \%)$ are in ruin and were excluded from this analysis. Figure 4 shows the distribution of these different types of buildings in the urban area. In the following sections, buildings with a rectangular or L-shaped floor plan are addressed, as they represent $91.36 \%$ of the island's residential buildings.

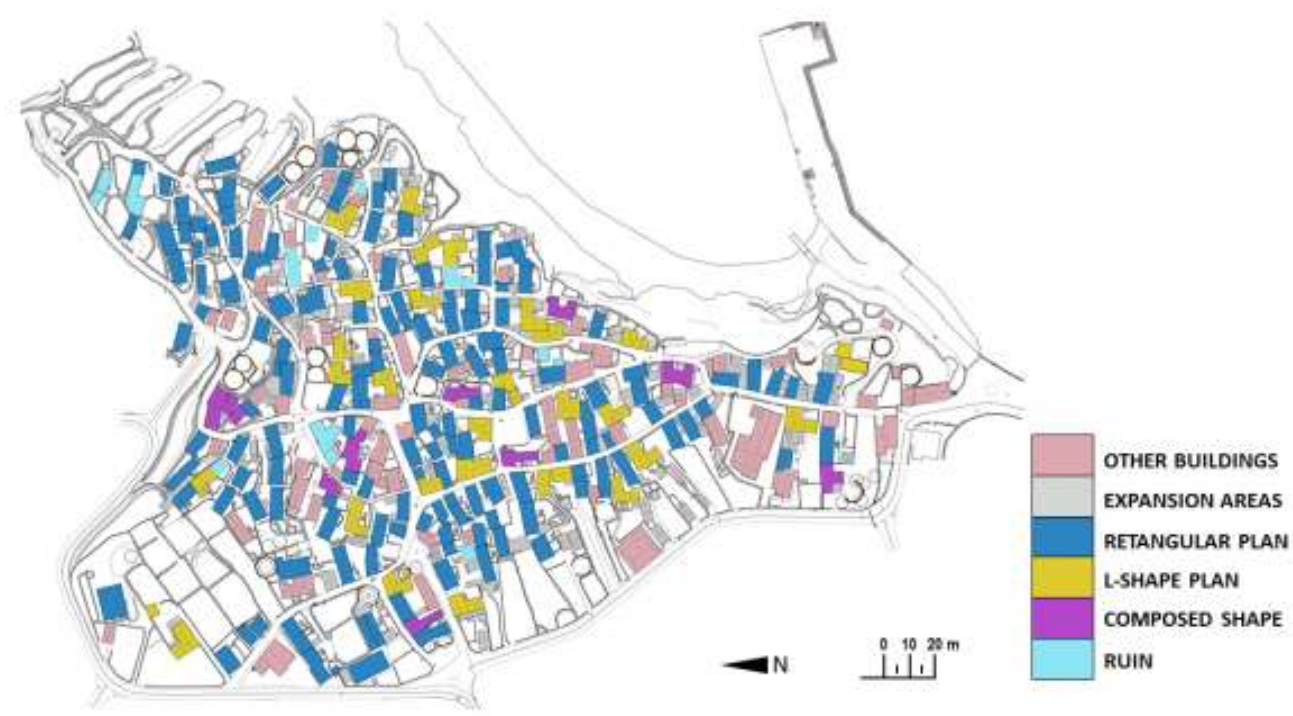

Figure 4. Location of the different types of buildings in the urban grid.

Volumetric Characterization and Functional Organization of Buildings with a Rectangular-Shaped Floor Plan

The buildings with a rectangular-shaped floor plan usually present a perimeter characterized by a smaller side, 4 to $6 \mathrm{~m}$ long, and a larger side, 12 to $13 \mathrm{~m}$ long. The smaller facade is, in general, parallel to the street, which determines the urban design. The smallest dimension is closely related to the geometry and technology adopted for the construction of gable or hip-shaped roofs. In exceptional cases, the smallest dimension can decrease up to $3 \mathrm{~m}$ and the largest dimension can reach $16 \mathrm{~m}$.

To define types of buildings with similar characteristics within the group of rectangular buildings, (i) the number of floors and (ii) the existence or not of interior and exterior stairs 
were considered (see Table 1 for different types of buildings with a rectangular-shaped floor plan and Figure 5 for these types' spatial distribution on the urban grid).

Table 1. Different types of rectangular-shaped floor plan buildings.

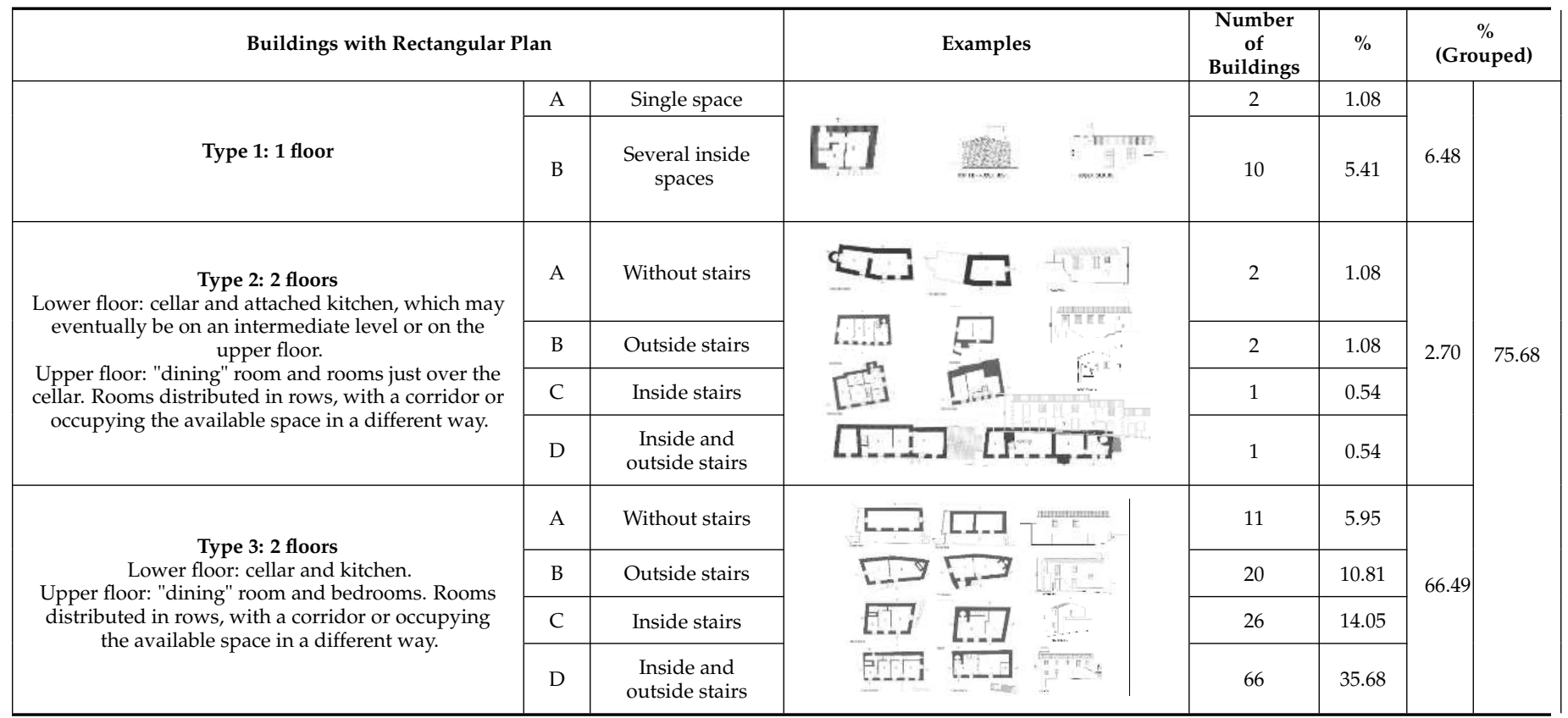

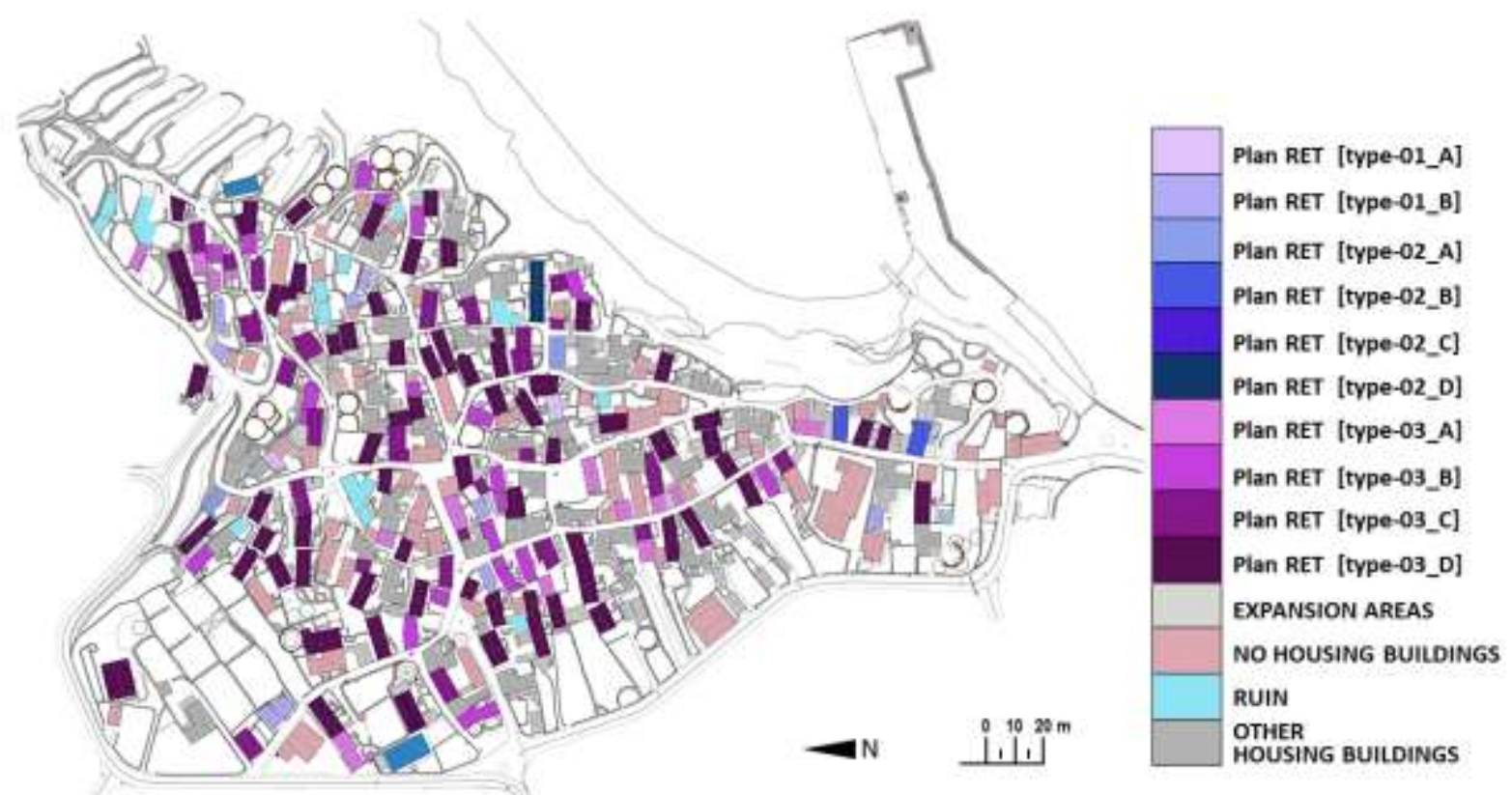

Figure 5. Distribution of the types of rectangular-shaped floor plan buildings in the urban grid.

The importance of types 3_D, 3_C, and 3_B of rectangular-shaped buildings in the NAVC characterization is unquestionable, since they represent about $60 \%$ of all residential buildings. In Figure 6, detailed drawings of four examples of type 3_D buildings are presented (which only differ from types 3_B and 3_C in having exterior stairs and interior stairs, respectively). These examples' functional organization can be briefly described as follows: 
I. Rooms are distributed in a corridor; interior wood-fired oven, whose chimney is a column of hot air; skewed exterior stairs—with balcony; "dining room" is located opposite the kitchen;

II. Rooms are accessible through a "dining room" space; interior wood-fired oven, whose chimney is a column of hot air; exterior stairs skewed in relation to the facade-with balcony; "dining room" is located opposite the kitchen;

III. Rooms are distributed through a "dining room" space, without a corridor; exterior wood-fired oven, whose chimney is a column of hot air; exterior stairs parallel, but not close, to the facade, with balcony; "dining room" is located opposite to the kitchen; and

IV. Rooms are distributed in a row, with corridor; exterior wood-fired oven, whose chimney is a column of hot air; exterior stairs perpendicular to the facade-with balcony; living room is located opposite the kitchen.

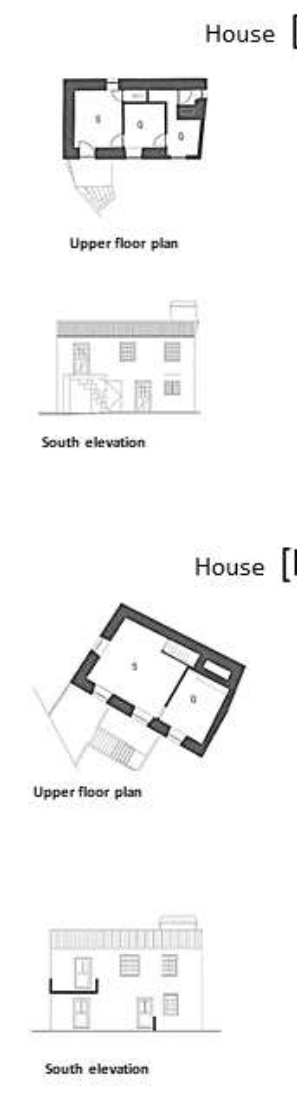

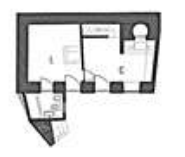

Lower floor plan

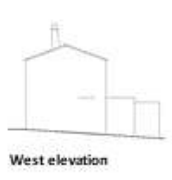

West elevation

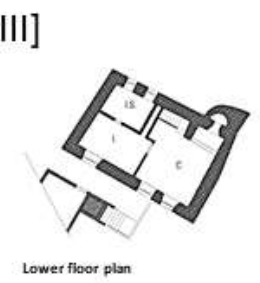

Lower floor plan

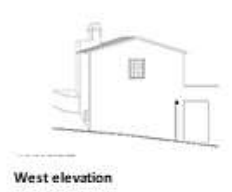

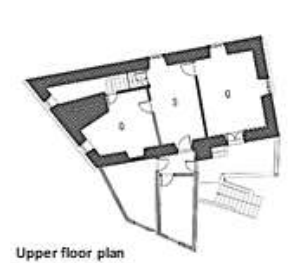

House [II]

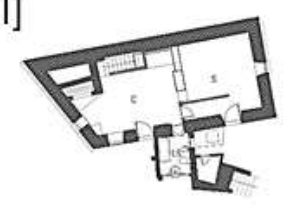

Lower floor plan
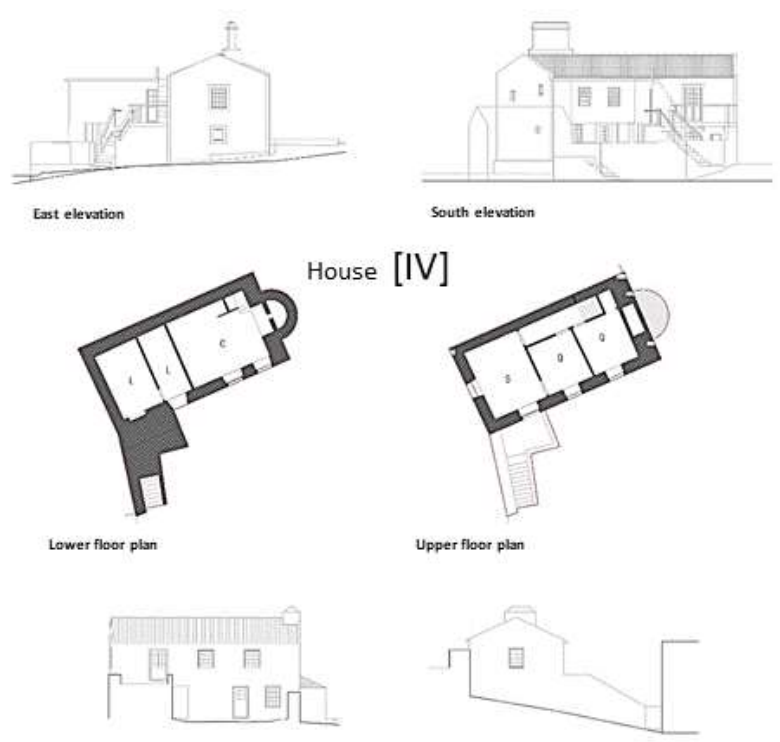

South elevation
[IV]

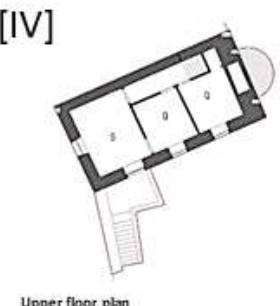

Upper floor plan

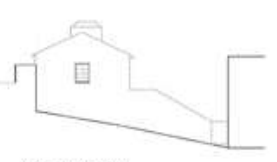

West elevation

Figure 6. Detailed drawings of four examples of type 3_D rectangular-shaped floor plan buildings.

Volumetric Characterization and Functional Organization of Buildings with an L-Shaped Floor Plan

Buildings with an L-shaped floor plan result, in general, from the combination of two rectangles with a width similar to the smaller dimension of the rectangular buildings, but with a shorter length. The two rectangles may have different dimensions, but their scale is generally similar.

For the definition of types of buildings with similar characteristics within the group of L-shaped floor plan buildings, the same parameters were adopted: (i) number of floors and (ii) the existence, or not, of either interior or exterior stairs.

Table 2 shows the different types of buildings with an L shape. Figure 7 shows these types' spatial distribution on the urban grid. 
Table 2. Different types of L-shaped floor plan buildings.

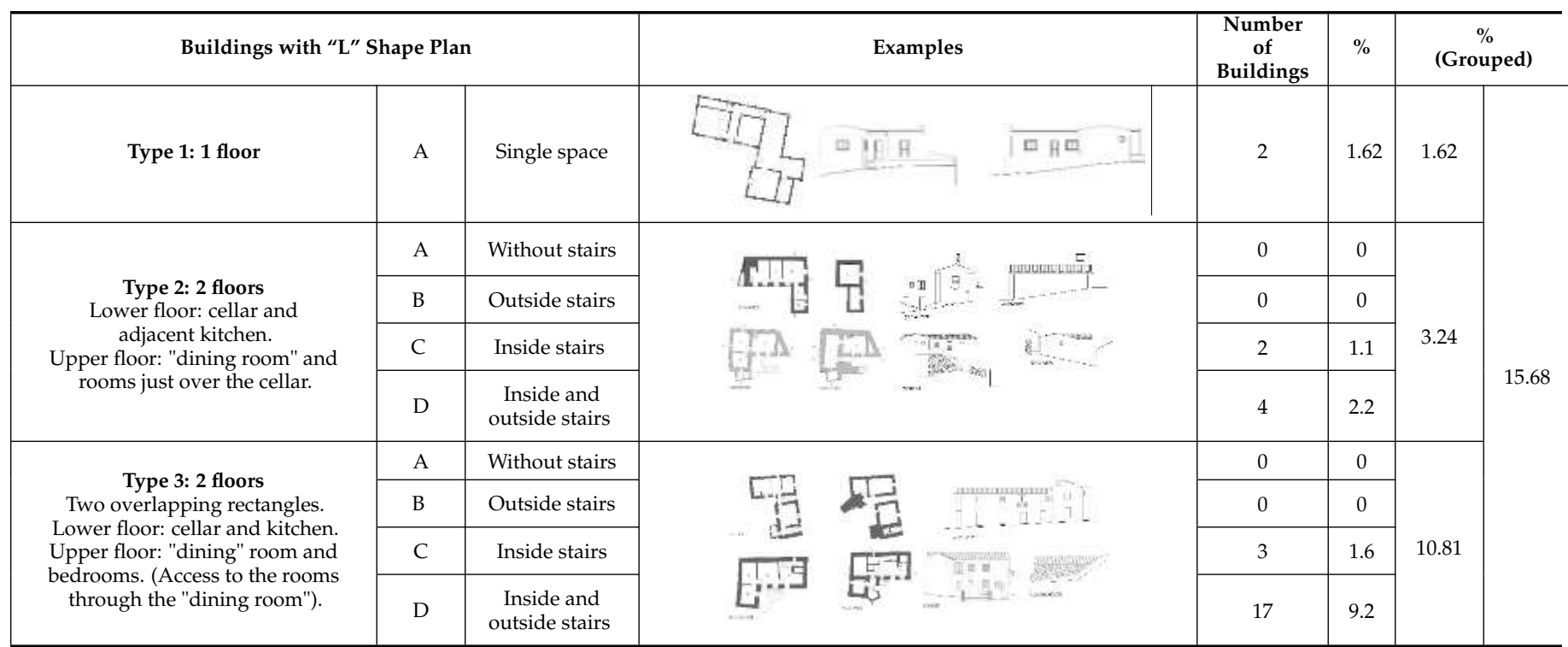

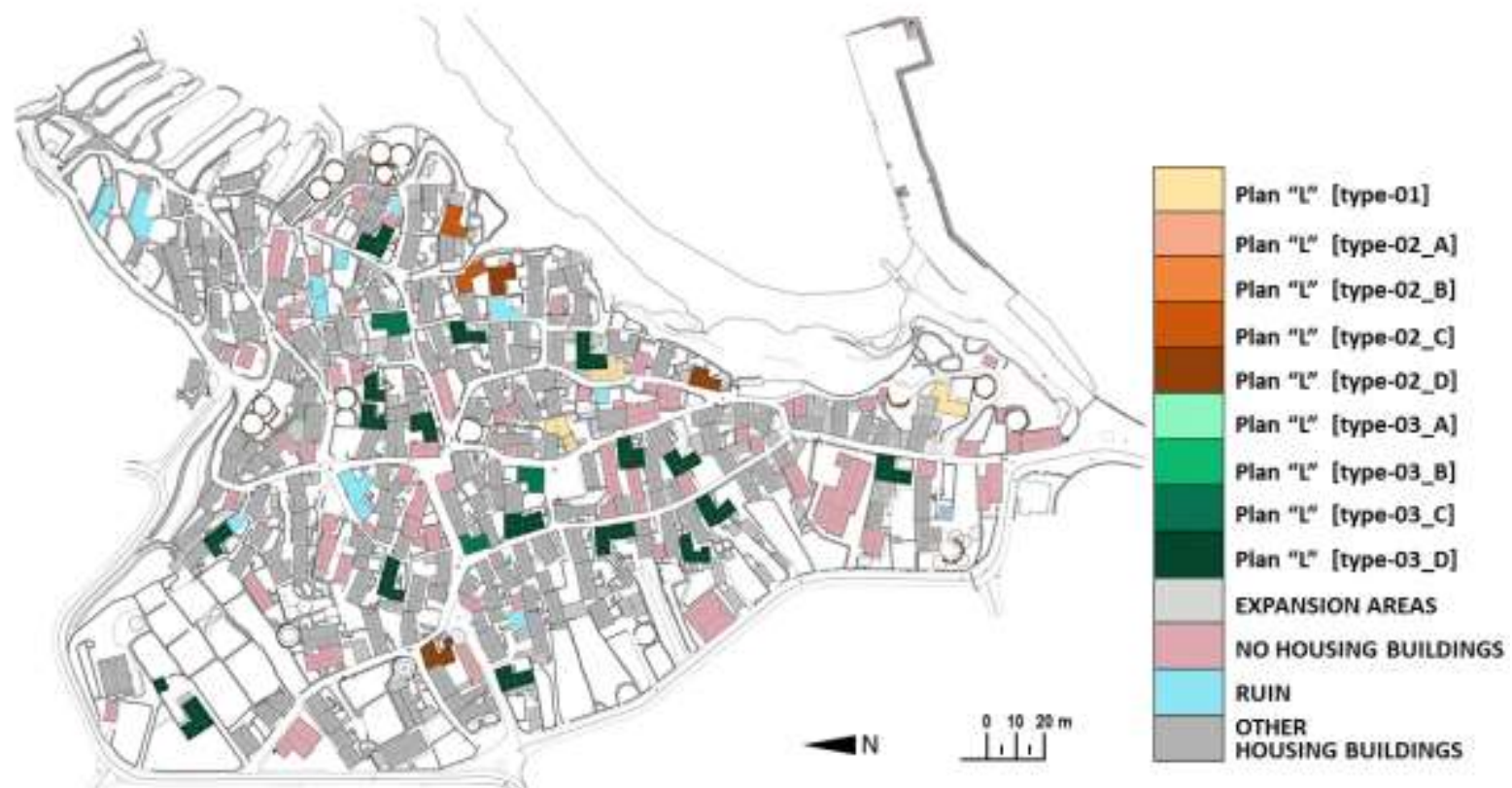

Figure 7. Distribution of L-shaped floor plan building types in the urban grid.

Like rectangular-shaped floor plan buildings, type 3_D buildings' predominance is significant (two floors with indoor and outdoor stairs). In Figure 8, detailed drawings of two examples of buildings of this type are presented, whose functional organization can be briefly described as follows:

V. Rooms are distributed practically in a row, with a corridor; inexistence of wood-fired oven; chimney is a column of hot air; exterior stairs parallel to the facade-with balcony; "dining room" is located opposite the kitchen; kitchen space occupies a section of the L; and

VI. Rooms are distributed in a row, with corridor; existence of exterior wood-fired oven and exterior chimney; exterior stairs parallel to the facade; "dining room" is located opposite the kitchen; kitchen occupies a section of the L. 

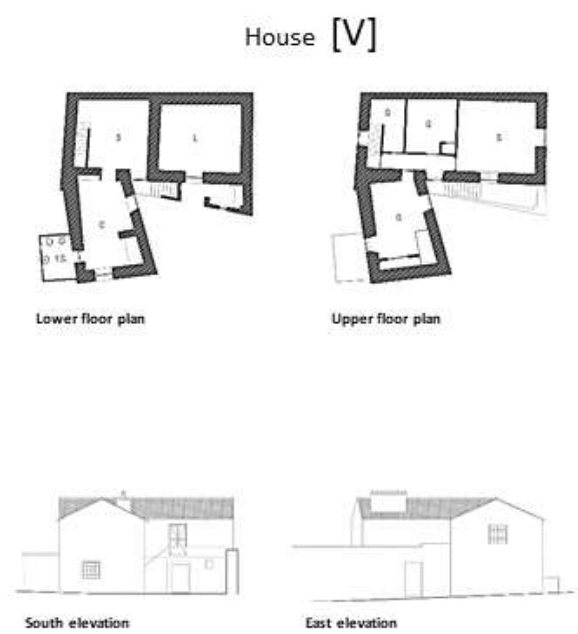

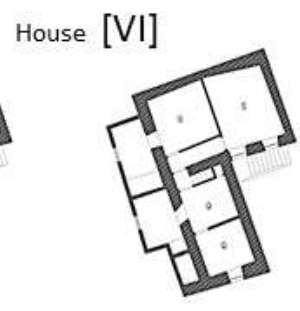

Upper floor plan
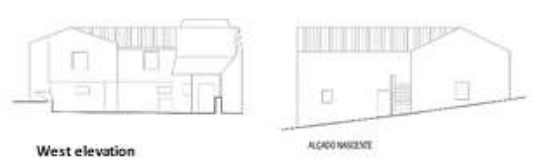

0

Figure 8. Detailed drawings of two examples of 3_D-type L-shaped floor plan buildings.

\subsection{Constructive Characterization}

This section presents the constructive characterization of the housing stock that composes NAVC. Information regarding walls, windows, interior stairs, and floors is presented. The characterization of roofs, exterior stairs, and smoke evacuation systems is presented in the next section, which is specifically dedicated to these singular features that are described.

Exterior walls of the NAVC buildings are composed of local volcanic stones, especially basalt, trachyte, and volcanic tuff. The masonry walls present a medium thickness of $64 \mathrm{~cm}$. This dimension is consistent with other masonry constructions in the Azores, especially considering an ancient construction measurement of length used in construction (equivalent to 1 côvado, corresponding to $66 \mathrm{~cm}$ ) [3]. Exterior walls are usually double leaf and are usually composed of stones of varied shape and size, although the use of regular prepared stone is usually reserved for a few buildings.

There are several solutions regarding joint material: clay, soil, or lime mortar. In some buildings the joint is not filled and other cases that have already suffered interventions have cement mortar.

The most common type of external wall coating is white-painted render, especially on the main and south facades, whereas the other walls are usually not covered with any kind of coating. However, there is also a significant number of buildings in which the stone masonry walls do not present any type of coating. In these cases, the gap between masonry joints of the external walls is either visible or cement mortar has been applied, presenting a wide variety of forms and shapes.

The internal partition walls on the upper floor are made of timber planks covered with plaster render (tabique). In the cases where recent interventions were carried out, some of the original partition walls were replaced with laminated plasterboard walls.

Regarding windows, most buildings have wood window framings, although aluminum and PVC solutions are becoming more common, indicating the existence of interventions where the original framings are being replaced. Buildings with different window framing materials are also very frequent. Considering window typologies, single-hung wood framing solutions are the most common, sometimes painted white or left unpainted. The general lack of window sills was also observed, which are frequently materialized by the stone supporting the window framing.

When there are stairs inside the dwellings, they are characterized by their steepness and narrowness, and usually made of wood. Their configuration is usually straight or winder (L-shaped), granting access to the upper floor through the kitchen, located on the ground floor. 
The ground floor pavement is characterized by being a simple earthen floor or screed, which usually has a ceramic coating or is left uncoated. On the upper floor, the structure of the pavement is composed of wooden beams, embedded in the gable end walls of the building and usually separated in $40-60 \mathrm{~cm}$ intervals. This structure is covered with wood plank flooring.

Figures 9 and 10 present several examples of the NAVC buildings' construction solutions described above.
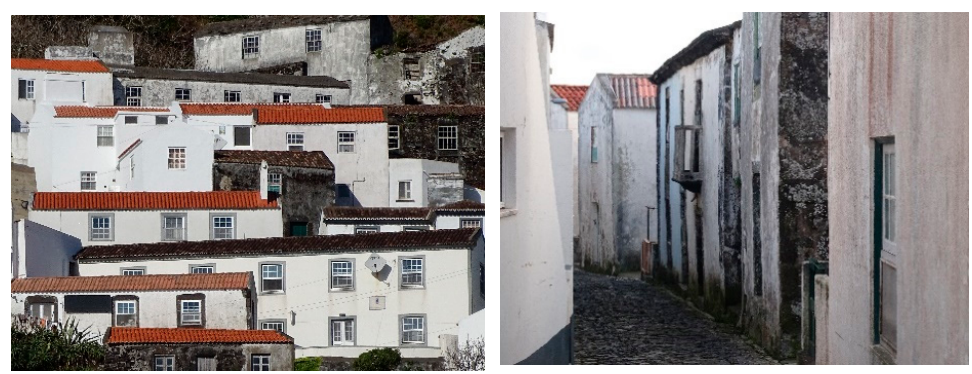

General view of

NAVC building

facades (1), a

group of buildings

facing a narrow

street (2).
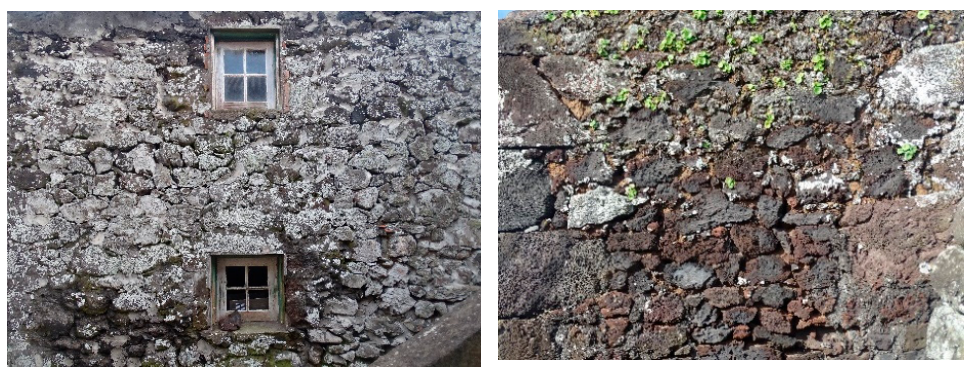

Examples of the different solutions of masonry apparatus and laying joint execution.
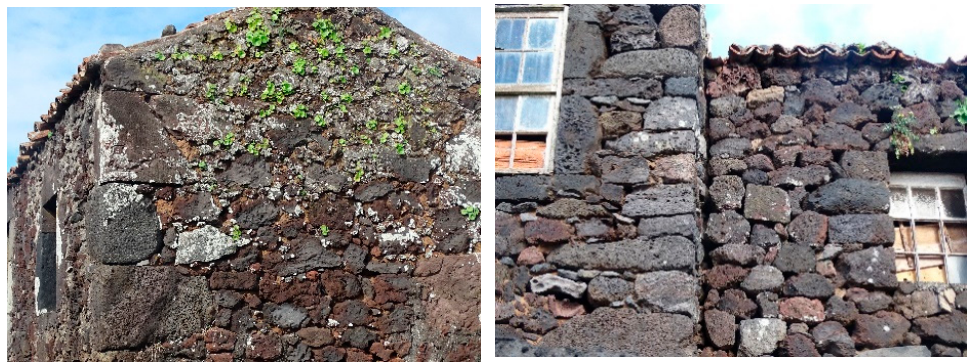

Examples of the masonry quoins, where the stones' disposition is essential for structural safety.
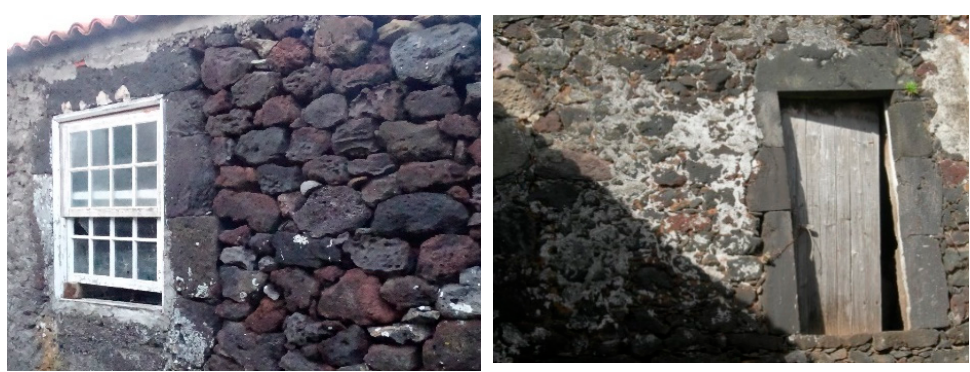

Examples of masonry framings bounding the openings for windows and doors in masonry facades.
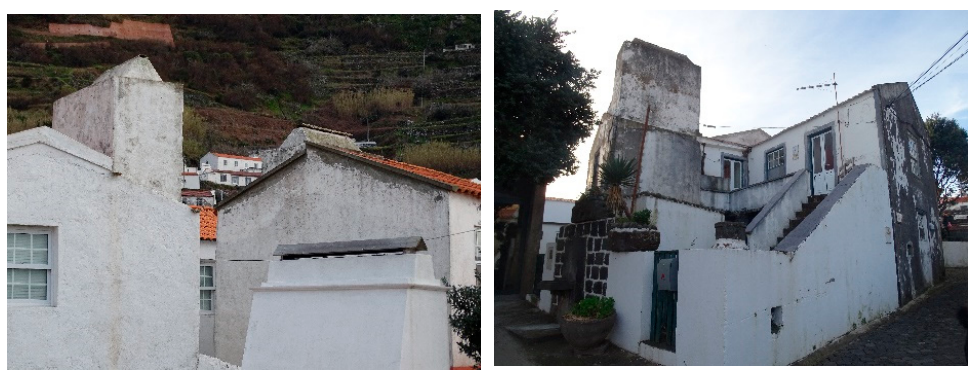

Examples of the chimneys.

Figure 9. Examples of NAVC buildings' construction solutions (part 1). 

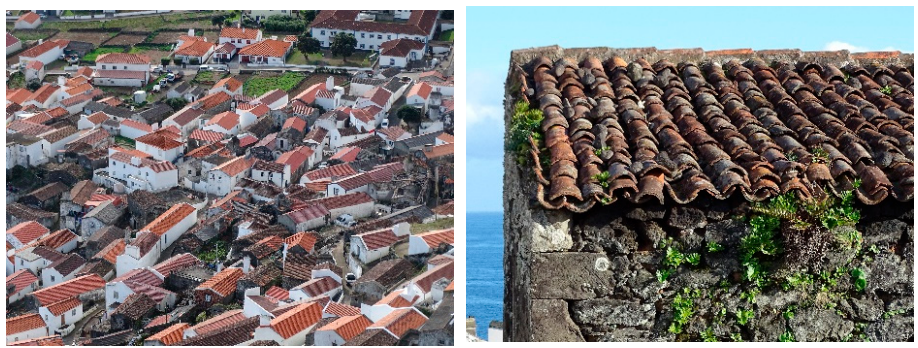

External view of pitched roofs, generally with two slopes, covered with clay tiles.
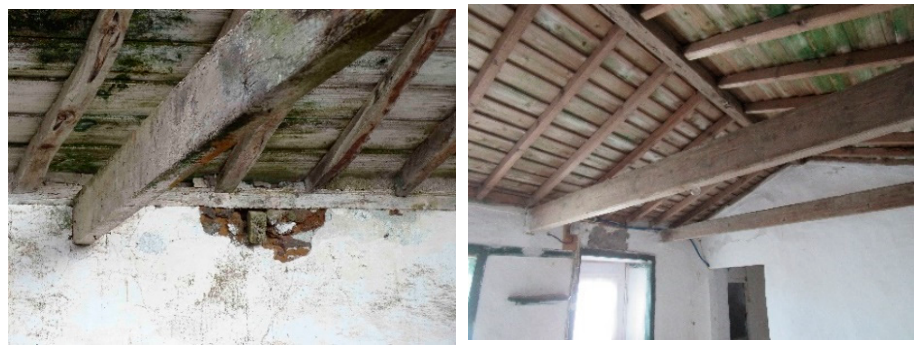

Internal view of pitched roofs, showing the wood structure.
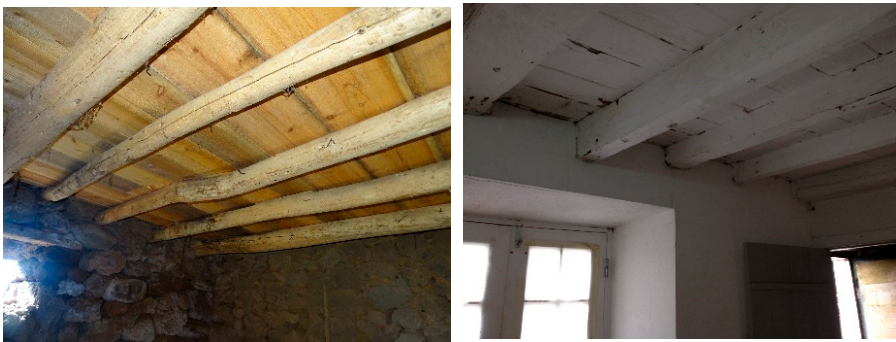

Timber floors of the upper floor and supporting structure: natural wood beams (1) and rectangularshaped wood beams (2).
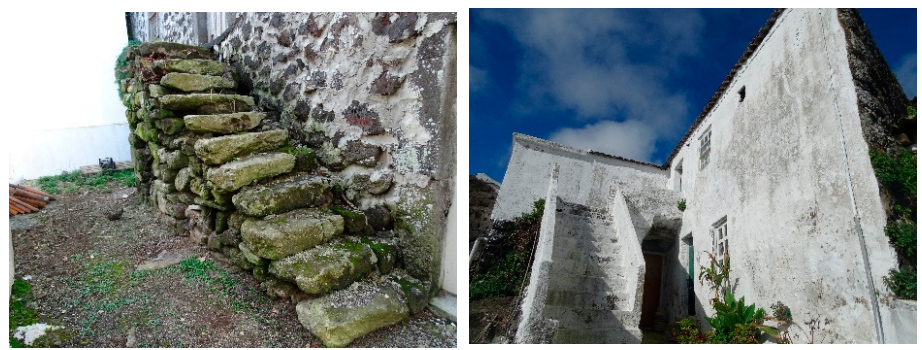

Examples of external stone masonry stairs.
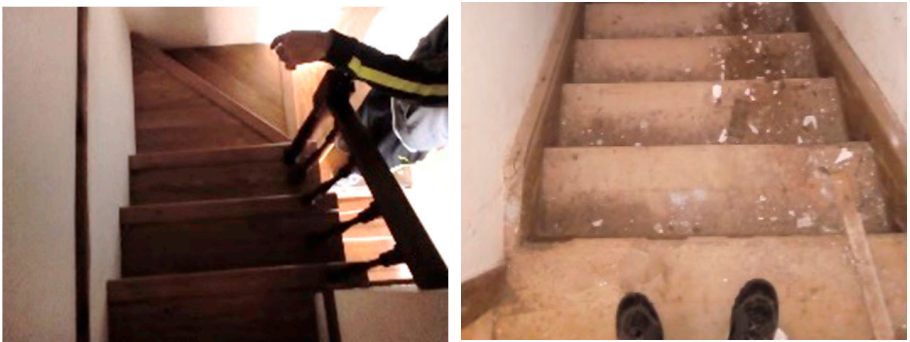

Examples of

narrow internal

stairs.

Figure 10. Examples of NAVC buildings' construction solutions (part 2).

\subsection{Singular Elements}

Besides the elements described in the previous section, the houses of NAVC have several singular characteristics that are clear indicators of the buildings' architectural and constructive value, justifying a detailed description and understanding of them.

The roof is typically a two-sloped pitched timber structure or, less frequently, hip shaped. Like other constructions in the Azores without timber trusses [3], the roof structures in NAVC are typically composed of a ridge beam and a set of rafters connected to the ridge beam at the top. Nonetheless, the ridge beam does not bear any load, only guaranteeing the position of the rafters. At the bottom, the rafters are supported by a load-bearing element 
connected to the inner leaf of the masonry wall, which runs throughout the perimeter, constituting a type of ring beam. To prevent horizontal movements on the wall due to the load of the structure, horizontal wooden tie beams are placed every $2 \mathrm{~m}$ (or four rafters), supporting the wall without any additional impulse. The timber element that supports the rafters fits on open spaces on the tie beams, immobilizing the rafters without exerting any horizontal impulse on the wall [23].

Roof coating is laid on tile battens that are placed over the rafters. The most common type of coating is ceramic tile, especially barrel type (pan and tile) [35], although there also is a significant number of solutions with fiber cement panels.

The second singular element of NAVC are the exterior stairs, observable in almost every building. These elements connect the first floor of the dwellings with the street and are composed of volcanic masonry blocks with significant dimensions. The stair configuration is straight, and they are usually parallel to the south facade. When there is a gap between the stairs and the wall next to them, the space under the stairs is usually used as storage, a bathroom space, or as a place to keep animals.

The last singular element consists of smoke evacuation systems composed of smokehouses, wood-fired ovens, and chimneys. Not all buildings have all these elements, but most of them have at least one, chimneys being the most common.

Traditionally, most NAVC houses had a wood-fired oven and a smokehouse, both located inside the kitchen compartment on the ground floor of the dwelling. Smoke evacuation chimneys that went through the upper floor all the way through the roof were built later, to avoid smoke concentration inside the building. By this time, wood-fired ovens started to be built on the exterior, inside a small compartment next to the kitchen but outside of the building perimeter. The current nonexistence of these elements in some of the buildings is most likely due to the changes that have been made to housing dwellings over time, eliminating some of these elements that are no longer used.

Figure 11 presents examples of the described NAVC building singularities.
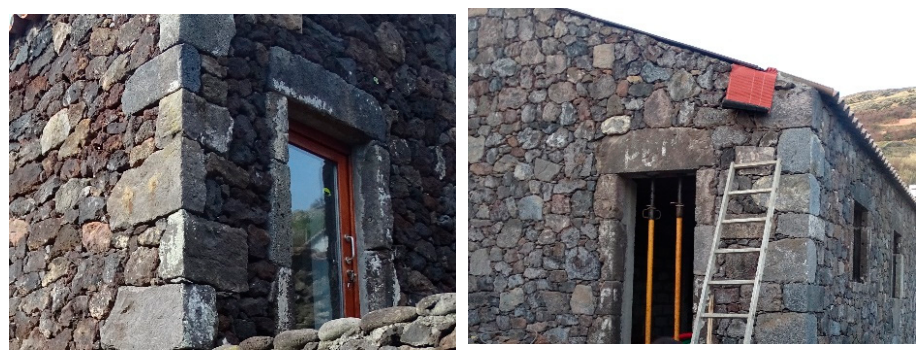

Some new

buildings adopt

the traditional

stone masonry for

the external wall.
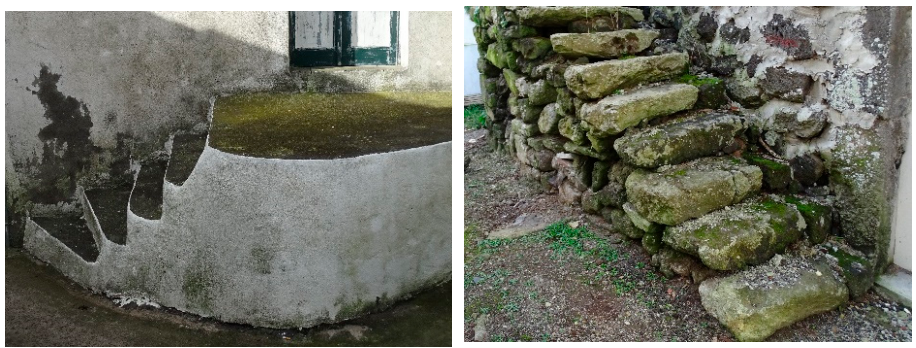

External stair

solutions.
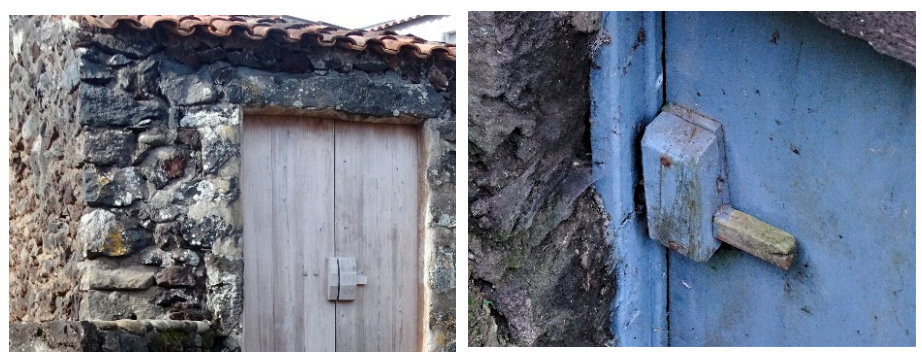

One of the most

traditional

singularities of the

buildings are the

wooden door

locks, avoiding

corrosion

problems.

Figure 11. Examples of NAVC buildings' details and singularities. 


\section{Conservation and Rehabilitation Challenges}

\subsection{Basis for Integrated Interventions}

The awareness of the need for an integrated intervention for the conservation and rehabilitation of buildings in NAVC is not recent, but it was only formally recognized in late 2015 with the publication of the Regional Regulatory Decree No. 20/2015/A, from 27 October, which approved the "Specific Regime for the Protection and Enhancement of the Built Cultural Heritage of the Old Centre of Vila do Corvo (NAVC)" [36].

In the preamble of this regulatory framework defined by the Regional Government of the Azores the following can be read:

“( ... ) In fact, the NAVC today shows evident signs of physical degradation and abandonment of properties, many of which are in an advanced state of ruin, to which is added a significant range of changes to the traditional typology of buildings, which over time have been taking place in immediate response to the natural desire for better conditions of habitability and comfort, however constituting itself as an improvised response, often precarious and counterproductive from the point of view of safeguarding and promoting heritage values that justify protection in cause (... )."

The main rehabilitation challenges are thus clearly established and can be summarized as follows [23]:

a. Structural stability, including the replacement of the buildings' resistant capacity or its reinforcement;

b. Durability, so as to stop progressive degradation processes and the replacement or creation of protective barriers, in particular against atmospheric agents such as the wind and sea;

c. Healthiness and comfort, ensuring better conditions of humidity and temperature, tactile and visual comfort, and safety in current use; and

d. Architectural and constructive enhancement, either by reinforcing or restoring constructive coherence, or by reinforcing and enhancing the identity of the buildings.

To provide an integrated response to these challenges, it was necessary to conduct an exhaustive characterization of the buildings composing NAVC, already presented in previous sections, and also a profound assessment of their conservation conditions and of the dissonances introduced over time. Despite not being the main focus of this article, the most relevant results of these studies are presented in the following sections.

However, it is not enough to correct anomalies and eliminate dissonances to achieve the goals of protecting and valuing the existing heritage. Furthermore, improving environmental performance and, fundamentally, improving quality of life, in response to residents' expectations and the ambition of local development policies, are also fundamental steps towards this final goal.

This work implies [23]:

a. Comprehensive and structured local survey of buildings;

b. Understanding traditional solutions, and their advantages and constraints;

c. Identification of new construction techniques and their compatibility with existing solutions; and

d. Careful design processes that combine respect for the general principles set out above with the uniqueness of each dwelling and each family, not forgetting the severity of the climate on the island of Corvo.

The Local Technical Office prepared around 80 proposals in response to these concerns, using, whenever necessary and in a judicious way, new technologies and new materials, with the aim of maintaining the identity of both the building and the urban setting. It is also important to consider the evolutionary process of the buildings, which have been, in some cases, modified throughout the years to respond to specific needs of the inhabitants. These alterations have led to the creation of singularities and, consequently, represent specific challenges that are necessary to consider individually and attentively.

In the last section of this chapter, one of these projects is briefly presented. 


\subsection{NAVC Buildings' Conservation State}

From the observation of the buildings of NAVC and the analysis of their state of conservation, four levels of degradation were defined:

a. Degradation level IV-The existing building is mainly composed of remaining parts of the previous wall structures, which have already collapsed (ruin state);

b. Degradation level III-The building is only composed of the exterior walls (the roof, intermediate floor structures or both, have already collapsed). The building thus maintains its external structure intact, yet without resistance capacity;

c. Degradation level II-The building has walls, a roof, and an intermediate floor. However, the structure of the middle floor is unstable, has evidence of structural damage to the roof, or both. The buildings have pathologies such as lack of material, namely with voids in their stone walls, among others; and

d. Degradation level I-The building does not have structural damage, despite having other anomalies capable of being corrected.

Degradation level I, related to non-structural anomalies, was the object of a detailed complementary study to identify the different types of anomalies [22], where defects in roofs, wall coverings, and windows were highlighted, with problems of humidity, cracking, aging of materials, and maladjustment in view of current functional requirements. Figure 12 illustrates the different levels of degradation and Figure 13 shows the location of buildings in the urban grid according to this classification.
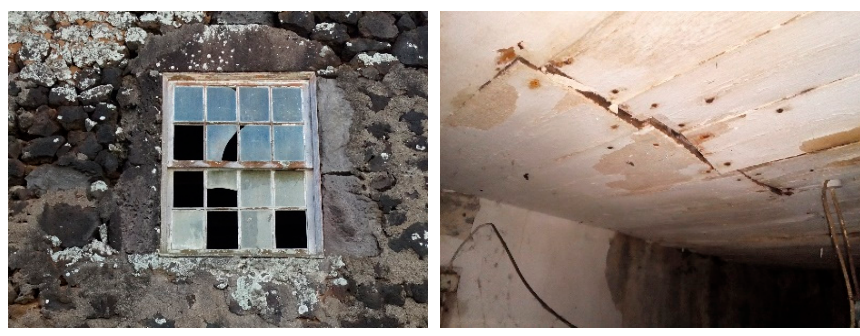

Examples of levels of degradation I (non-structural anomalies) and II (specific structural degradation).
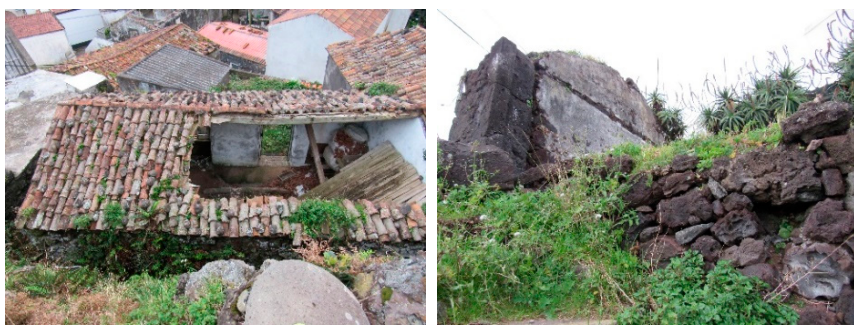

Examples of degradation levels III (partial ruin) and IV (total ruin).

Figure 12. Examples of building degradation situations.

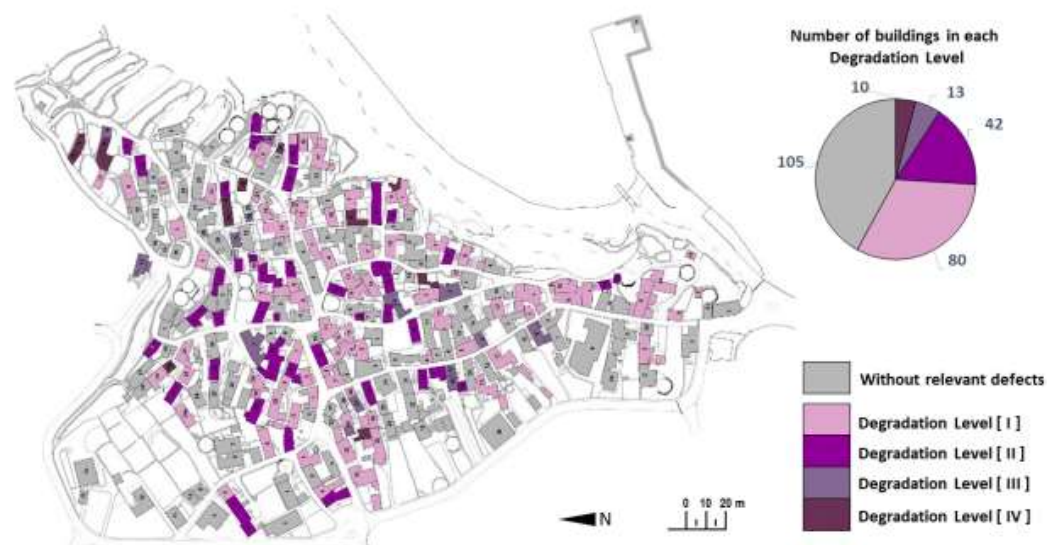

Figure 13. Number and location of buildings, according to the level of degradation. 


\subsection{NAVC Buildings' Dissonances}

As mentioned in the Regulatory Decree [36], many interventions carried out over the years were not framed by a global strategy, nor supported by a detailed project, often leading to dissonances that need to be evaluated and, when necessary and possible, corrected. From the observation of the NAVC buildings, 26 types of alterations performed on buildings were considered to have led to significant dissonances. The buildings were grouped into levels of dissonance according to the following criteria: Level I-Does not present dissonances; Level I-Low: one to three dissonances; Level II-Medium: four to six dissonances; Level III-High: contains seven to nine dissonances; Level IV-Very high: contains more than 10 dissonances. Figure 14 illustrates some of the dissonances observed and Figure 15 shows the location of buildings in the urban grid according to this classification.
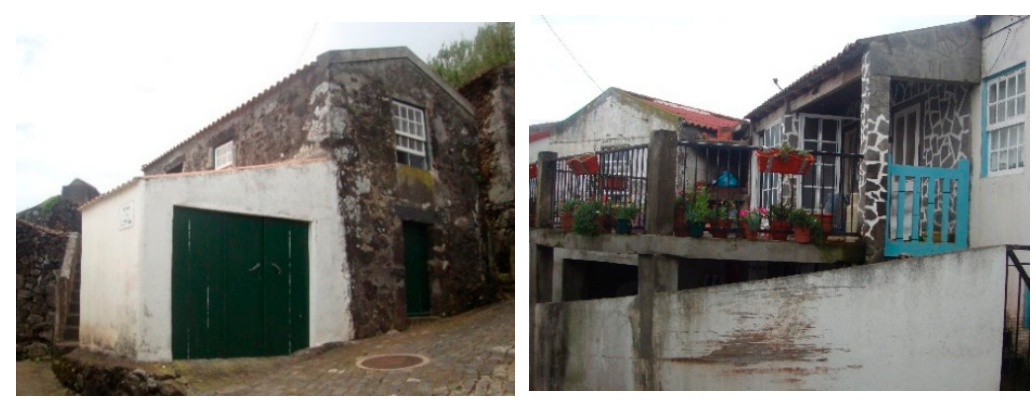

Examples of dissonances due to (left) illegal enlargements and (right) the use of non-traditional building materials.
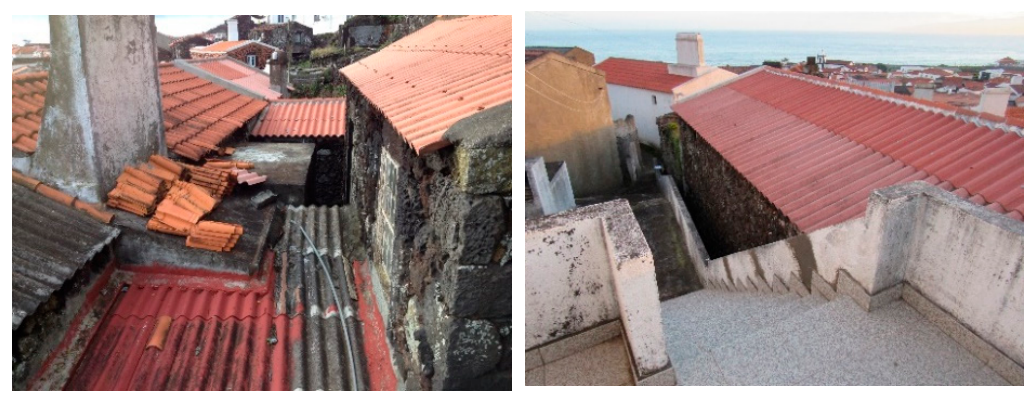

Examples of dissonances in roofs due to irregular expansion of buildings and the use of metal and fiber cement panels.
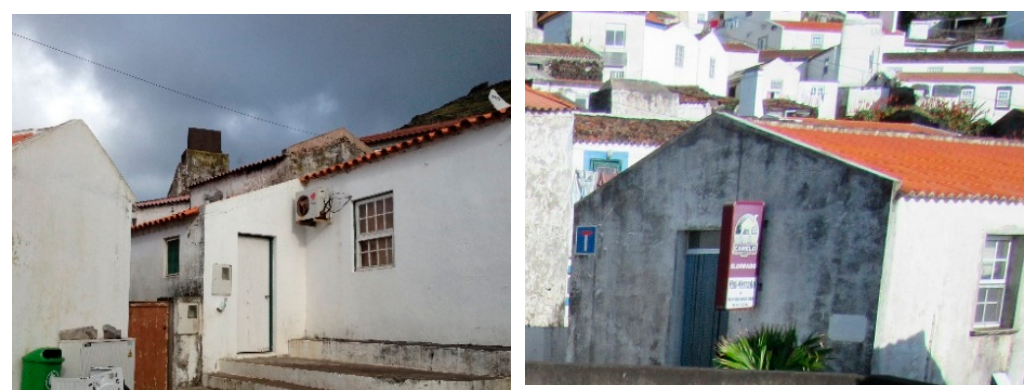

Examples of dissonances in facades due to the installation of technical equipment and advertising panels without proper integration.

Figure 14. Examples of observed dissonances in NAVC buildings.

\subsection{Example of NAVC Building' Rehabilitation Intervention}

The example selected to exemplify the projects developed for about 80 residential buildings in NAVC, within the scope of the integrated rehabilitation project, is a small building with a rectangular-shaped floor plan, two floors, and a traditional gabled roof, with external stairs.

All construction solutions are characteristic of typical NAVC buildings: exterior supporting walls in stone masonry, and interior walls in a traditional wood system (tabique) covered with plaster render. 


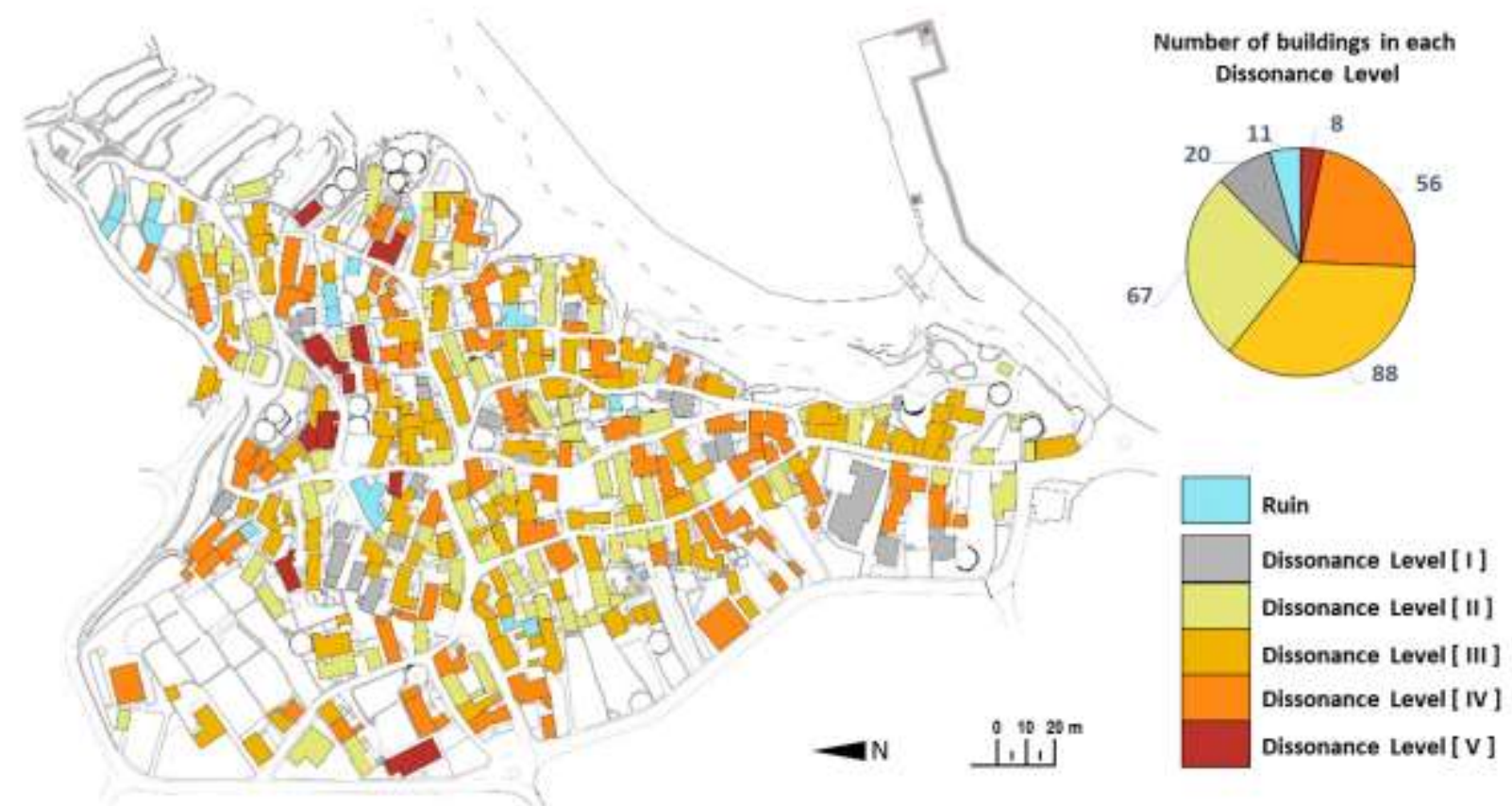

Figure 15. Level of the dissonance number and the location of the buildings in the urban grid.

Figures 16 and 17 present general views of the building and the architectural survey, respectively.
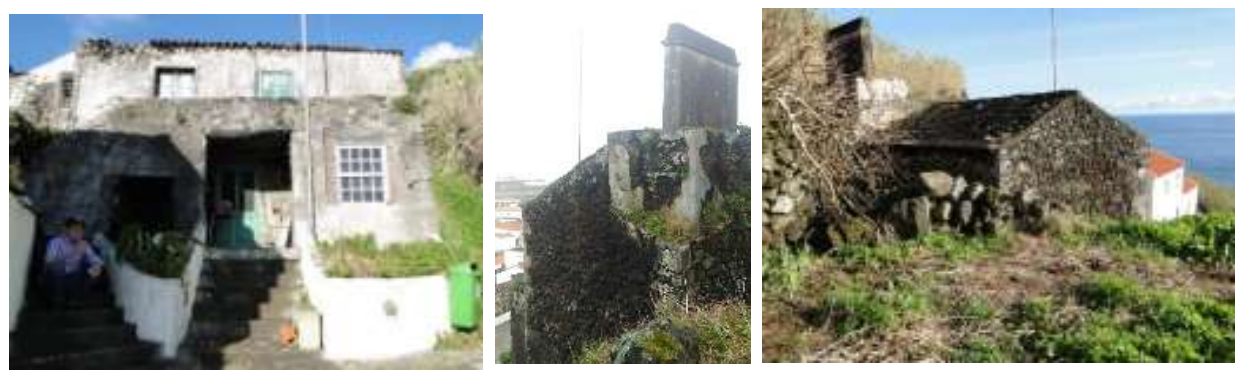

Figure 16. General views of the building surveyed.

On the lower floor there are two spaces separated by a masonry wall made of concrete blocks, which resulted from unfinished work for the eventual creation of a bathroom. The larger space has a mixed function between "cellar" and kitchen, with an exterior wood-fired oven. The pavement consists of a mortar screed executed directly on the ground.

The interior connection between the two floors is made through a reinforced concrete stairway that is totally different from the original construction system. The upper floor has a wooden structure and is in a significantly bad state of conservation. The degradation of the roof is also severe.

The upper floor consists of a single habitable compartment, used as a bedroom. The habitability conditions of the building are very bad, not only due to its degradation, but also due to the small space and the lack of basic equipment and functionalities.

The difficulties resulting from partial and very poor interventions carried out over time also contribute to the lack of suitable living conditions. Thus, the challenge of the intervention was to make the most of the space and provide the house with suitable living conditions, respecting the guidelines of the specific regulations created in 2015 by the Regional Government of the Azores. Figure 18 presents architectural plans for the intervention proposal. 


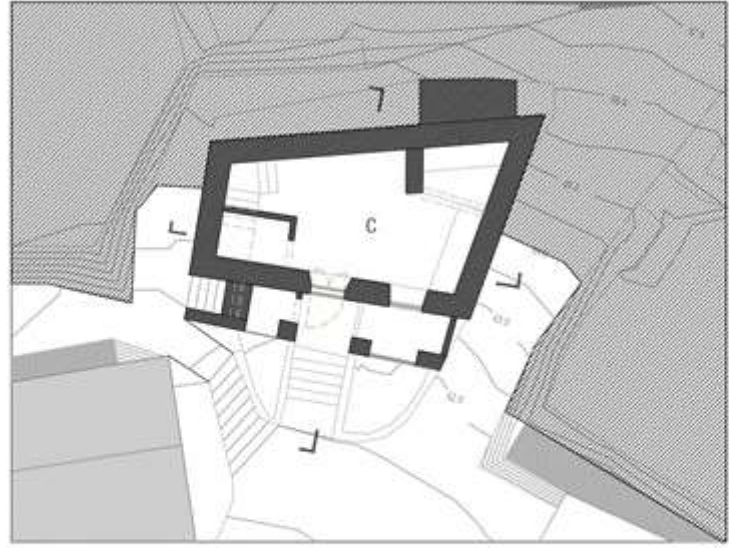

Lower floor plan

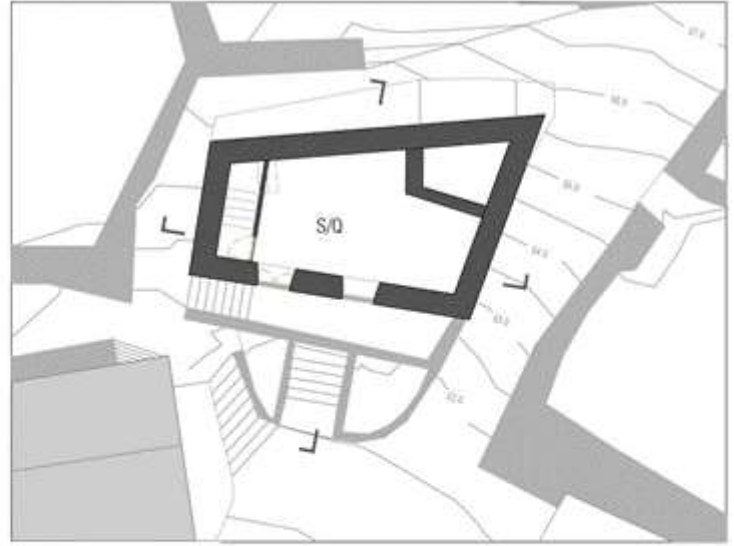

Upperfloor plan

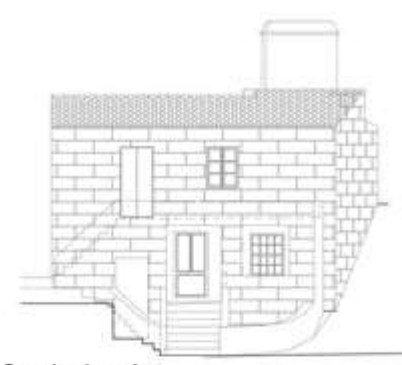

South elevation

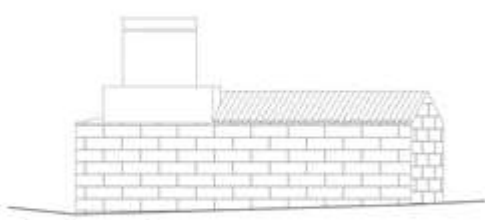

North elevation

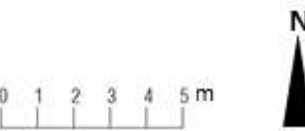

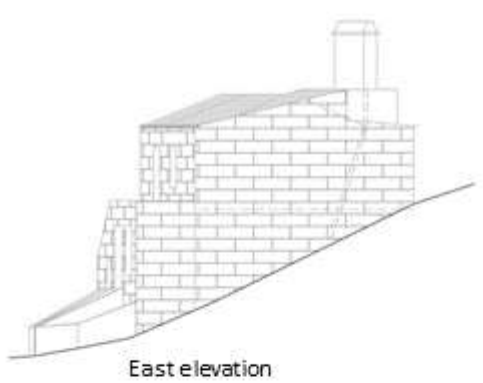

East elevation

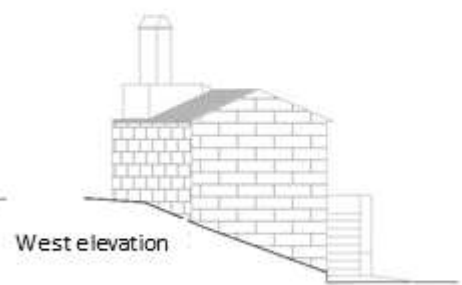

L Cellar

C Kitchen

Q Bedroom
IS Bathroom

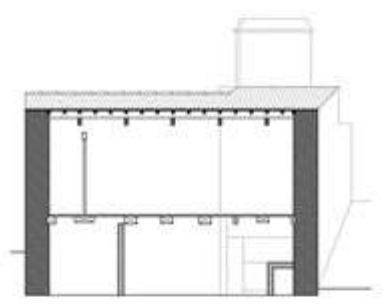

Longitudinalsection

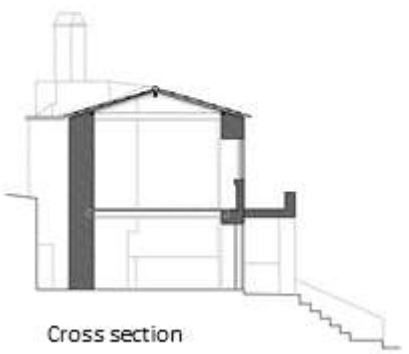

Figure 17. Example of the architectural survey of one building.

The dismantling of the stone stairs and their subsequent reuse is foreseen, as well as the construction of a small space to install a bathroom, which would be articulated with the original building.

The lower floor level would be lowered to increase the space's height. This floor would be reorganized to maintain and improve the kitchen functions, now including the "dining room" function. Here, the dissonant elements would be demolished. The interior access to the upper floor would be replaced by a wooden staircase, which would replace the concrete staircase. On the upper floor the spatial organization would be maintained, but with improved comfort and healthiness and with the exclusive function of a bedroom.

In view of the poor conservation state of the existing wooden floor of the upper floor, it was decided to reconstruct it with an identical technical solution.

The windows and doors would also be replaced by traditional wooden solutions, but with better performance than the existing ones. The same strategy would be adopted with the roof, taking the opportunity to make a slight correction of geometry and to create a technical element of lighting and ventilation. 


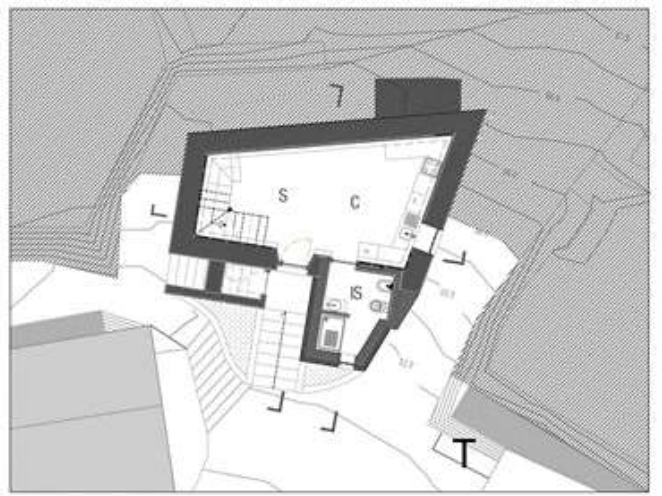

Lower floor plan

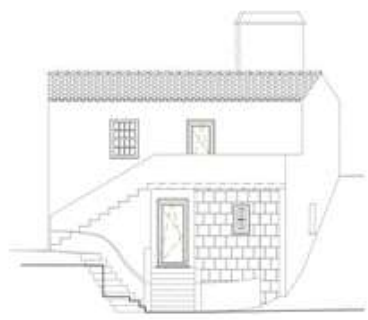

South elevation

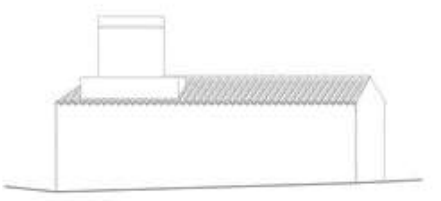

North elevation

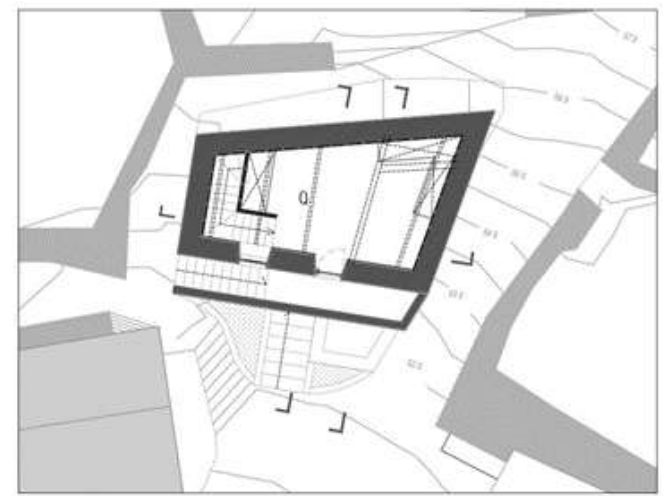

Upperfloor plan
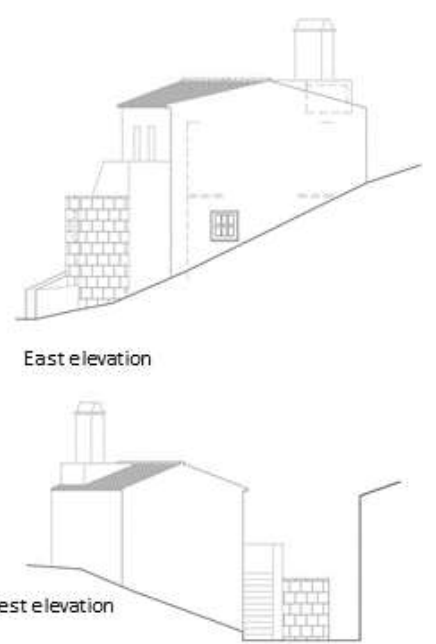

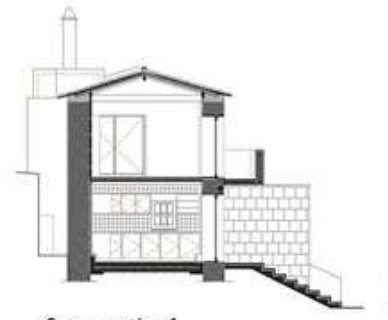

Cross section 1

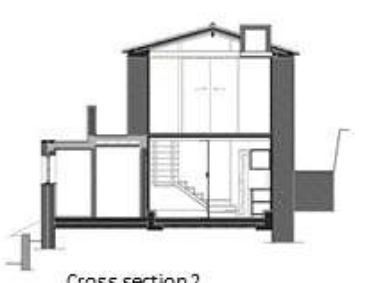

Cross section 2

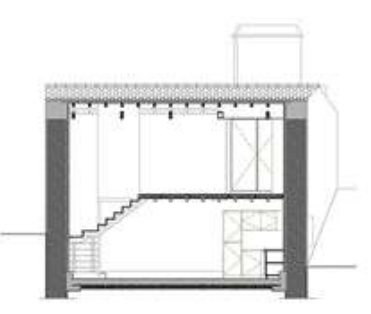

Longitudinaisection

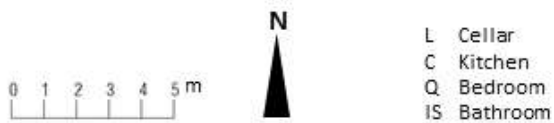

Figure 18. Architectural plans for the intervention proposal.

This project, like all those that were developed in this integrated plan of valorization of NAVC by the Local Technical Office, aimed to answer the rehabilitation challenge considering, simultaneously, the principles of protection and valorization of the existing environmental preservation and progressive improvement of quality of life. Although the policy, strategies, methods, and technologies are the same, as required in an integrated action, the implementation of interventions requires adequate solutions for each dwelling.

\section{Conclusions}

For its inhabitants, living in Corvo represents safety, happiness, peace, friendship, cohesion, solidarity, and pride. Despite being isolated and still suffering from certain 
difficulties, this territory has unique characteristics that are valued by its community and visitors.

The settlement of Corvo Island is characterized by its originality: an island with only one inhabited place. Vila do Corvo is a testament to the evolution of the community and its houses, which date back to 16 th and 17th centuries. The village is proof of the continuous effort to adapt to the adverse climate and the scarcity of local resources.

Here, any intervention on the buildings should have as a main objective the improvement of the quality of life of its inhabitants. However, this objective must also consider the concerns of protecting and valuing the identity of existing buildings and the concerns of environmental sustainability.

To achieve these objectives, it is necessary to have an integrated action supported by its own regulation by an exhaustive knowledge of the history of the place, the buildings and local construction techniques, expectations of its inhabitants, state of conservation, and dissonance of the buildings.

This paper presented the architectural and constructive characterization of NAVC buildings, as well the island's historical context and its resources. Additionally, a description of NAVC buildings' state of conservation was carried out, as well as the presentation of the dwellings' dissonances and of a rehabilitation intervention already carried out. The goal of this work is to contribute to a more extensive and profound knowledge of the island's built heritage, laying the foundations for future rehabilitation interventions that value this territory's unique identity and improve its inhabitants' quality of life.

The work developed showed a typical building morphology, structured in several variants, where rectangular buildings with two floors are the most frequent. The buildings are compact and are strongly related to construction technology, namely roofing.

The internal organization of the dwellings is very much conditioned by the typical volume of the buildings and, in many cases, does not correspond to the current requirements of comfort and healthiness. Thus, many projects have as a main objective the correction of these limitations.

Several anomalies were also identified that mainly resulted from climatic aggressiveness and low maintenance. The projects developed also aim to correct these defects and, as far as possible, contribute to the elimination or mitigation of dissonances resulting from the most disqualified interventions carried out over the years.

Through the example presented it is confirmed that it is possible to articulate the different functional objectives, both with the preservation of the buildings' identity and with sustainability requirements, through a philosophy of minimal intervention and maximizing the buildings' longevity.

Author Contributions: All authors contributed equally to this paper and approved the final manuscript. Conceptualization, J.M.S.; Formal analysis, V.M.; Investigation, A.I.P.S., C.P.M. and L.C.; Methodology, A.I.P.S.; Project administration, L.C.; Supervision, V.M. and J.M.S.; Validation, C.P.M.; Writingoriginal draft, C.P.M., L.C. and J.M.S. All authors have read and agreed to the published version of the manuscript.

Funding: Financed by national funds through the I\&D entity Geosciences Center (CGEO), UIDB/00073/2020 through FCT—Fundação para a Ciência e Tecnologia, I.P.

Institutional Review Board Statement: Not applicable.

Informed Consent Statement: Not applicable.

Data Availability Statement: Not applicable.

Acknowledgments: The authors acknowledge the collaboration of Regional Directorate for Culture of Azores.

Conflicts of Interest: The authors declare no conflict of interest. 


\section{References}

1. Resolução do Governo Regional dos Açores n. ${ }^{\circ}$ 69/97. Published in JORAA, 1. ${ }^{a}$ série, n. ${ }^{\circ}$ 15, 10th April 1997. Available online: http://ot.azores.gov.pt/store/sarups/432/COR-Res69_97.pdf (accessed on 12 February 2021).

2. Lei n. ${ }^{\circ} 107 / 2001$, Que Estabelece as Bases da Política e do Regime de Proteção e Valorização do Património Cultural. Published

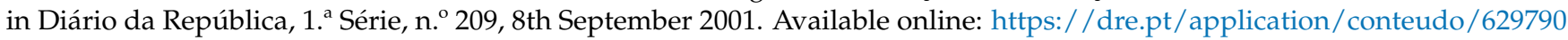
(accessed on 12 February 2021).

3. Neves, F.; Costa, A.; Vicente, R.; Oliveira, C.S.; Varum, H. Seismic vulnerability assessment and characterisation of the buildings on Faial Island, Azores. Bull. Earthq. Eng. 2012, 10, 27-44. [CrossRef]

4. Dinis, F.A.M. Contributo Para a Caracterização Construtiva e da Vulnerabilidade Sísmica de Edifícios no Centro Histórico de Angra do Heroísmo. Master's Thesis, Civil Engineering, University of Coimbra, Coimbra, Portugal, 2020.

5. Bezzeghoud, M.; Borges, J.F.; Caldeira, B.; Buforn, E.; Udias, A. Seismic activity in the Azores Region in the context of the western part of the Eurasia-Nubia plate boundary. In Proceedings of the International Seminar on Seismic Risk and Rehabilitation on the 10th Anniversary of the July 9th 1998 Azores Earthquake, Horta-Azores, Portugal, 9-13 July 2008; pp. $27-31$.

6. Morais, E.C.; Ferreira, T.M.; Estevão, J.M.C.; Oliveira, C.S. Implementation and validation of an approach for the estimation of the magnitude of historical earthquakes in Azores Islands. Int. J. Disaster Risk Reduct. 2021, 53, 102000. [CrossRef]

7. Ferreira, T.M.; Maio, R.; Vicente, R. Analysis of the impact of large scale seismic retrofitting strategies through the application of a vulnerability-based approach on traditional masonry buildings. Earthq. Eng. Eng. Vib. 2017, 16, 329-348. [CrossRef]

8. Fagundes, C.; Bento, R.; Cattari, S. On the seismic response of buildings in aggregate: Analysis of a typical masonry building from Azores. Structures 2017, 10, 184-196. [CrossRef]

9. Teves-Costa, P.; Oliveira, C.; Senos, M.L. Effects of local site and building parameters on damage distribution in Angra do Heroísmo-Azores. Soil Dyn. Earthq. Eng. 2007, 27, 986-999. [CrossRef]

10. Medeiros, C. Os Açores e o Atlântico (Séculos XIV-XVII), Primórdios do comunitarismo numa ilha atlântica—o Corvo. In Proceedings of the Colóquio Internacional, Volume XLI, Instituto Histórico da Ilha Terceira, Angra do Heroísmo, Portugal, 8-13 August 1983.

11. Medeiros, C. A Ilha do Corvo, 2nd ed.; Livros Horizonte: Lisboa, Portugal, 1997.

12. Vergílio, M.H.S.; Calado, H.G.P. Spatial planning in small islands: The need to discuss the concept of ecological structure. Plan. Pract. Res. 2016, 31, 452-471. [CrossRef]

13. EcoMuseu do Corvo: Proposta de Intervenção Museológica. Visão estratégica, Proposta de Plano de Ação. Available online: http:/ / www.culturacores.azores.gov.pt/ecomuseu-do-corvo/ecomuseu.pdf (accessed on 4 January 2020).

14. Geoportal do Laboratório Nacional de Energia e Geologia. Available online: https://geoportal.lneg.pt/mapa/\# (accessed on 15 January 2021).

15. UNESCO: Recommendation on The Historic Urban Landscape. Available online: https://whc.unesco.org/uploads/activities/ documents / activity-638-98.pdf (accessed on 12 February 2021).

16. Sanna, A.; Ortu, G.G. I Manuali di Recupero dei Centri Storici Della Sardegna: Geografie Dell'abitare; DEI: Roma, Italy, 2009.

17. Varagnoli, C. La Tutela Difficile: Patrimonio Architettonico e Conservazione a Pescara; MAC Edizioni: Corfinio, Italy, 2019.

18. Crespo, I.J. Arquitectura vernácula de la Sierra de Gredos y el valle del Alto Tormes (Ávila): Análisis tipológico, fundamentos constructivos y funcionamiento bioclimático. Cuad. Abulenses 2011, 40, 43-76.

19. Garcia-Esparza, J.; Pardo, F.; Palmero, L.M. A multi-analysis characterization of medieval and vernacular coating mortars in rural Valencia (Spain): An experimental study for a Heritage Action Plan. J. Cult. Herit. 2018, 31, 83-96. [CrossRef]

20. Branco, I.M.S. O Lugar do Aeroporto, Uma Estratégia Para a Sua Reabilitação. Master's Thesis, Building Rehabilitation, University of Coimbra, Coimbra, Portugal, October 2020.

21. Centro Histórico de Angra do Heroísmo nos Açores. Available online: http:/ /www.patrimoniocultural.gov.pt/pt/patrimonio/ patrimonio-mundial/portugal/centro-historico-de-angra-do-heroismo-nos-acores/ (accessed on 12 February 2021).

22. Salvador, A.I.P. Passado, Presente e Futuro do NAVC: A Casa “Corvina”. Master's Thesis, Building Rehabilitation, University of Coimbra, Coimbra, Portugal, December 2020.

23. Silva, J.M.; Mouraz, C.P.; Catarino, L. Contributo para a caracterização construtiva do edificado antigo da ilha do Corvo no âmbito do projeto do EcoMuseu. In Proceedings of the Construção 2018: Construir e reabilitar de forma sustentável, Porto, Portugal, 21-23 November 2018; pp. 1007-1015.

24. Descobrimento dos Açores in Infopédia. Available online: https://www.infopedia.pt/\$descobrimento-dos-acores (accessed on 12 February 2021).

25. Leite, A.R. Açores, Cidade E Território. Quatro Vilas Estruturantes; Instituto Açoriano de Cultura: Angra do Heroísmo, Portugal, 2014.

26. Neves, D.; Silva, C.A. Modeling the impact of integrating solar thermal systems and heat pumps for domestic hot water in electric systems- The case study of Corvo Island. Renew. Energy 2014, 72, 113-124. [CrossRef]

27. Cordeiro, P.A. História Insulana das Ilhas a Portugal Sujeitas no oceano Occidental; Typ. Do Panorama: Lisbon, Portugal, 1899.

28. Dias, J. Geologia e Tectónica da Ilha do Corvo (Açores-Portugal): Contributos Para o Ordenamento do Espaço Físico. Master's Thesis, University of Coimbra, Coimbra, Portugal, 2001; 80p.

29. Melo, C.S.; Ramalho, R.S.; Quartau, R.; Hipólito, A.; Gil, A.; Borges, P.A.; Cardigos, F.; Ávila, S.P.; Madeira, J.; Gaspar, J.L. Genesis and morphological evolution of coastal talus-platforms (fajãs) with lagoons: The case study of the newly-formed Fajã dos Milagres (Corvo Island, Azores). Geomorphology 2018, 310, 138-152. [CrossRef] 
30. Calado, H.; Borges, P.; Phillips, M.; Ng, K.; Alves, F. The Azores archipelago, Portugal: Improved understanding of small island coastal hazards and mitigation measures. Nat. Hazards 2011, 58, 427-444. [CrossRef]

31. Medeiros, S.; Fernandes, I.; Fournier, B.; Nunes, J.C.; Ramos, V. Hawaiian and Azorean volcanic aggregates: A preliminary study of the potential alkali-silica reaction. Bull. Eng. Geol. Environ. 2020. [CrossRef]

32. Madeira, M.; Pinheiro, J.; Madruga, J.; Monteiro, F. Soils of volcanic systems in Portugal. In Soils of Volcanic Regions in Europe; Arnalds, Ó., Bartoli, F., Buurman, P., Óskarsson, H., Stoops, G., García-Rodeja, E., Eds.; Springer: Berlin/Heidelberg, Germany; New York, NY, USA, 2007; pp. 69-81. Available online: https://link.springer.com/chapter/10.1007/978-3-540-48711-1_8 (accessed on 4 January 2020).

33. Triantis, K.A.; Borges, P.A.V.; Ladle, R.J.; Hortal, J.; Cardoso, P. Extinction debt on oceanic islands. Ecography 2010, 33, 285-294. [CrossRef]

34. Boieiro, M.; Matthews, T.J.; Rego, C.; Crespo, L.; Aguiar, C.A.S.; Cardoso, P. A comparative analysis of terrestrial arthropod assemblages from a relict forest unveils historical extinctions and colonization differences between two oceanic islands. PLoS ONE 2018, 13, e0195492. [CrossRef] [PubMed]

35. Grimmer, A.E.; Williams, P.K. Preservation Briefs 30: The Preservation and Repair of Historic Clay Tile Roofs; U.S. Department of the Interior National Park Service Cultural Resources: Washington, DC, USA, 1992.

36. Decreto Regulamentar Regional n..$^{\circ}$ 20/2015/A-Regime Específico de Proteção e Valorização do Património Cultural Imóvel do Núcleo Antigo de Vila do Corvo; Published in Diário da República: 1. ${ }^{a}$ série, n. ${ }^{\circ}$ 210, 27 October 2015. Available online: http:/ / www.culturacores. azores.gov.pt/ficheiros/legislacao/2015111285434.pdf8 (accessed on 4 January 2020). 